\title{
Historic Perspectives on Annonaceous Acetogenins from the Chemical Bench to Preclinical Trials
}

Authors

Affiliations
Chih-Chuang Liaw ${ }^{1,2}$, Tung-Ying $\mathbf{W u}^{3}$, Fang-Rong Chang ${ }^{3}$, Yang-Chang $\mathbf{W u}^{3,4}$

${ }^{1}$ Graduate Institute of Pharmaceutical Chemistry, College of Pharmacy, China Medical University, Taichung, Taiwan

${ }^{2}$ Department of Life Sciences, National Chung-Hsing University, Taichung, Taiwan

${ }^{3}$ Graduate Institute of Natural Products, Kaohsiung Medical University, Kaohsiung, Taiwan

${ }^{4}$ Cancer Center, Kaohsiung Medical University Hospital, Kaohsiung, Taiwan

\author{
Key words \\ - Annonaceae \\ - acetogenins \\ - mitochondria complex I \\ inhibitor \\ - pesticidal activity \\ - anticancer activity \\ - apoptosis \\ - acetogenin mimics
}

$\begin{array}{ll}\text { received } & \text { Nov. 30, 2009 } \\ \text { revised } & \text { April 26, 2010 } \\ \text { accepted } & \text { April 28, 2010 }\end{array}$

Bibliography

DOI http://dx.doi.org/

10.1055/s-0030-1250006

Published online June 24, 2010

Planta Med 2010; 76:

1390-1404 @ Georg Thieme

Verlag KG Stuttgart - New York .

ISSN 0032-0943

Correspondence

Dr. Yang-Chang Wu
Graduate Institute of Natural

Products

Kaohsiung Medical University

100 Shih-Chuan 1st Road

703 Kaohsiung

Taiwan

Republic of China

Phone: + 88673121101

ext. 2197

Fax: + 88673114773

yachwu@kmu.edu.tw

\section{Abstract}

$\nabla$

Studies on the Annonaceous acetogenins began after the first cytotoxic acetogenin, uvaricin, was isolated in 1982. This attractive finding made many medicinal and natural product chemists direct their efforts on the isolation and identification of these classes of compounds. As more Annonaceous acetogenins were isolated, more information about them was uncovered. From their structural identification to the total synthesis of natural product analogues and from cell-based screening and molecular-based targeting to animal testing, the mechanisms of action of the Annonaceous acetogenins became clearer. The purpose of this review is to give an account of recent studies on this class of compounds and their analogues, which will aid us not only in clarifying how the Annonaceous acetogenins act but also in establishing principles for the further development of this class of compounds.

\section{Abbreviations \\ $\nabla$}

AGE: Annonaceous acetogenin

APICID: atmospheric pressure in-source

CC:

CCC:

CD:

Complex I: collision-induced dissociation column chromatography countercurrent chromatography circular dichroism

Dansyl-NH: NADH: ubiquinone oxidoreductase

DIP:

EI-MS:

ESI-MS:

FITC:

H125: electron-spray ionisation mass spectrometry 1-yl-sulfonamide electron-impact mass spectrometry

fluorescein isothiocyanate lung adenocarcinoma cells
H23:

H8:

HCT-8:

HSCCC:

HT-29:

$\mathrm{IC}_{50}$ :

ITC:

K562:

KB 3-1:

LC/MS:

$\mathrm{LT}_{50}$ :

M17/Adr:

MCF-7/Adr:

MCF-7/wt:

MDA-MB-468: human mammary adenocarcinoma cells

MDR:

NADH:

NBD-NH: multiple-drug resistant nicotinamide adenine dinucleotide, reduced form

NCI:

NMA:

P388:

P-gp:

PI:

PO:

PO3:

PS:

non-small cell human lung cancer cells

HPV16 subgenes-immortalised human endocervical cells intestinal adenocarcinoma cells high-speech countercurrent chromatography human colon cancer cells the half maximal inhibitory concentration isothermal titration calorimetry human immortalised myelogenous leukaemia line human epidermoid carcinoma cells liquid chromatography/mass spectrometry median lethal time adriamycin-resistant murine mammary cells adriamycin-resistant human mammary adenocarcinoma cells nonresistant human mammary adenocarcinoma cell wild type

7-nitrobenzo[c][1,2,5]oxadiazol4-yl-amino

National Cancer Institute naphthylmethoxyacetic acid murine lymphoblastoid cells P-glycoprotein mediated pumps propidium iodide oral administration pancreatic adenocarcinoma PS system (P-388 lymphocytic leukaemia in mice)

SAR: $\quad$ structure-activity relationship 
Sf9 cell:

$\mathrm{T} / \mathrm{C}:$

T24:

THF: pupal ovarian tissue of the Fall armyworm Spodoptera frugiperda

test/control

bladder cancer cells

tetrahydrofuran
THP:

TLC:

TMS:

YEM: tetrahydropyran

thin-layer chromatography

trimethysilyl

yellow fever mosquito larvae assay

\section{Introduction}

$\nabla$

Plants have a long history of use in the treatment of human diseases. Botanical extracts have long been regarded as a source of new and useful pharmaceuticals. According to Cragg's investigation, approximately $62 \%$ of commercially available drugs have natural product origins [1]. These natural products also play important roles as direct treatments or as templates (lead compounds) that are modified for the treatment of human diseases. The commonly known example from folkloric medicinal plants is the anticancer agent paclitaxol, a diterpene from Taxus brevifolia (Taxaceae) discovered by Wall and Wani in 1971 [2] that is now used for the treatment of advanced ovarian cancer. Other examples of anticancer drugs derived from natural products, such as camptothecin from Camptotheca acuminata (Nyssaceae) [3], podophyllotoxin from Podophyllum peltatum [4], vincristine and vinblastine from Vinca rosea [5], and adriamycin from Streptomyces peucetius [6], have encouraged pharmaceutical chemists to search for new drugs from medicinal plant sources.

Annonaceous acetogenins (AGEs) are a unique class of $C_{35}$ or $C_{37}$ secondary metabolites of Annonaceous plants derived from the polyketide pathway. Extensive studies on AGEs have indicated that these naturally occurring compounds possess a broad spectrum of bioactivity, including anticancer, antiparasitic, insecticidal and immunosuppressive effects. In 27 years, more than 500 AGEs were isolated from various parts of the plants of this family [7-10]. These bioactive AGEs became more important, particularly in pharmaceutical research $[11,12]$. A great interest in investigating the mechanisms of action of a series of AGEs emerged from the leaps in knowledge about the processes involved in tumour cell death. Members of this class of natural compounds are regarded as "potential" candidates for future generations of anticancer drugs. AGEs have become one of the most interesting classes of natural products at present.

Annonaceous plants are important economic crops in Asia. There is an especially abundant biomass of Annonaceous plants in Taiwan. In our studies, AGEs from Formosan Annonaceous plants showed significant cytotoxicity against ovarian cancer cells, 1A9, with more potential than paclitaxol [13]. The purpose of this review is to give a short historical introduction as well as an account of the recent studies on AGEs and their analogues. This brief outline begins with a description of the sources, isolation, chemistry and biological activities of this class of natural compounds. Achievements in the studies of AGEs are noted by their significant cytotoxicity. Recent studies on the mechanisms of action of the pesticidal and antitumour AGEs are reviewed within the individual sections. In addition, modified analogues of AGEs and AGE mimics were made to verify hypotheses regarding the modes of action of the AGEs. Historically following the studies of the AGEs from the abundant natural biomass, it will be helpful for us to not only clarify how AGEs act but also establish the principles that will guide the further development of these natural products.

\section{Previous Studies on the AGEs before the 2000s}

$\nabla$

The isolation of uvaricin (1) from the roots of Uvaria accuminata Oliv. by Jolad et al. in 1982 and its excellent bioactivity in the PS test system initiated the studies on AGEs as a hot topic in drug discovery [14]. Following the experimental and major biochemical conceptual advances, the studies on AGEs during the early 1980s to about 2000 could be summarised in three stages, including the initial stage (before 1990), the middle stage (from 1991-1995), and modern stage (1996-2000). In the initial stage (before 1990), several groups, including McLaughlin's (Purdue, USA), Cave's (CNRS, France), Fujimoto's (Tokyo, Japan), Pettit's (Arizona, USA), and Sneden's (Virginia, USA), began efforts toward the isolation and structural identification of these types of bioactive compounds.

In the isolation procedure, AGEs were first concentrated via solvent partitioning driven by their amphiphathic properties. Methanol is usually the solvent of choice for the extraction of these AGEs from plant materials. By partitioning the crude extract with chloroform and water, the chloroform layer will become enriched with the AGEs. Chromatographic techniques, such as gradient elution column chromatography (CC), flash chromatography and preparative TLC, were generally utilised for the isolation and purification of these compounds. During this period of time the major population of AGEs was discovered. For example, the first mono-tetrahydrofuran (THF) AGE, annonacin (2), was isolated from Annona densicoma Mart [15]; the adjacent bis-THF AGE, squamocin (3), was isolated from A. squamosa L. [16]. The first nonadjacent bis-THF AGE, bullatalicin (4) [17], was isolated from A. bullata A. Rich. and was also isolated from A. cherimolia Mill as cherimoline (5) [18] (renamed by Cortes et al. as cherimolins-1 and 2 [19]). The first AGE with the saturated $\gamma$-lactone moiety, laherradurine (6), was isolated from $A$. cherimolia seeds, of which the structure was revised by the same group later $[19$, 20]. The primary structures of the AGEs were determined by ${ }^{1} \mathrm{H}-$ and ${ }^{13} \mathrm{C}$-NMR and mass spectroscopy, in which the former method (NMR) could confirm the presence of functional group substituents (the $\gamma$-lactone ring moiety and the oxygen-bearing moieties) and the latter (MS) could determine the placement of substituents along the carbon skeleton. Rupprecht et al. published the first review on AGEs in 1990 [7], reporting the strategies for their structural elucidation and revising some structures of the published compounds. At that time, three main types of AGEs, mono-THF, adjacent bis-THF and nonadjacent bis-THF, were classified based on the presence of the THF ring moieties.

The stereochemistry of the substituents of AGEs was mainly determined by organic syntheses of the partial structures and X-ray crystallography of the AGEs. Hoye et al. (Minnesota, USA) first proposed a valuable method for the quantitative correlation of the ${ }^{1} \mathrm{H}$-NMR chemical shift data for a series of model diastereomeric bis-tetrahydrofurans [21,22]. Pettit et al. first elucidated the relative stereochemistry of the eight chiral centres of rolliniastatin 1 (7), by X-ray structure determination of its $15-0$-p-bromophenylurethanic derivative, as $4 S^{*}, 15 S^{*}, 16 S^{*}, 19 R^{*}, 20 R^{*}, 23 S^{*}, 24$ $R^{*}, 36 R^{*}[23]$. However, the absolute configuration of rolliniastatin 
1 (7) should be the mirror image of the proposed structure because of its CD data [ $n-\pi^{*} \Delta \varepsilon(235)<0$ and $\left.\pi-\pi^{*} \Delta \varepsilon(220 \mathrm{~nm})>0\right][24,25]$, which indicates a $36 S$ configuration. In 1990, Born et al. proposed a systematic comparison of the ${ }^{1} \mathrm{H}$ - and ${ }^{13} \mathrm{C}-\mathrm{NMR}$ chemical shifts of the diagnostic protons for two diastereomers, which became a popular way to confirm the erythro and threo effects on the protons of the tetrahydrofuran rings [26]. Meanwhile, Hoye et al. proposed a symmetry-assisted synthesis of the bis-THF moiety [27]. Biosynthetically, the AGEs are regarded to originate from polyhydroxy C-32 or C-34 fatty acids, to which a 2-propanol unit is added to form the methylated $\alpha, \beta$-unsaturated $\gamma$-lactone. Hoye's proposed idea really matched the biosynthetic hypothesis for the construction of these compounds ( $\bullet$ Fig. 1).

Following the rapid development of chromatographic techniques in the early 1990s, studies on the AGEs in the middle stage (from 1991 to 1995) focused on the isolation and purification of various types of AGEs and the identification of the stereochemistry of AGEs by chemical methods. More laboratories worldwide became active in research related to the isolation, structural elucidation, and even total synthesis and mechanisms of anticancer action of these compounds. Our group also began studying the Formosan AGEs at this time.

Since the 1970s, our group has mainly studied the secondary metabolites from plants of the Lauraceae. Because of the close phylogenic relationships of both the Lauraceae and Annonaceae families, we started to study the secondary metabolites of the Formosan Annonaceous plants ( Table 1). In Taiwan, there are 21 species (8 genera) of Annonaceous plants, of which three, Fissistigama glaucescens (Hance) Merr., F. oldhami (Hemsl.) Merr. and Goniothalamus amuyon (Blanco) Merr., are native to the Taiwan island $[28,29]$. Our early studies on the Formosan Annonaceous plants focused on alkaloids, which showed diverse biological functions, including cytotoxicity [30], antiplatelet aggregation activity [31], cardiovascular activity [32,33] and antimicrobial activity [34]. Afterwards, diterpenoids, styrylpyrones [12,35,36] and some linear AGEs [37], mono-THF AGEs $[38,39]$, and adjacent bis-THF AGEs [39] were isolated from various parts of the Annona plants in our laboratory. Two groups in China also started related research on AGEs in China during that period $[40,41]$, one of which - Dr. Yang's group in Yun-Nan cooperated with us to elucidate the structures of the AGEs from A. muricata [42].

To improve the efficiency of the chromatography, repeated open column chromatography and high-performance liquid chromatography (HPLC) were introduced for the isolation of AGEs [4346] such that AGEs with minor structural differences could be isolated more easily and quickly. Based on the isolations of different AGEs, their general structural features can be divided into two classes: 1 ) the moiety of the $\gamma$-lactone rings: the $\alpha, \beta$-unsaturated $\gamma$-lactone ring (normal form) or the ketolactone (isoform) (see $\odot$ Fig. 2); and 2) the oxygen-bearing moieties (see $\odot$ Fig. 3) $[9,47]$. In addition, the structure of (-)-muricatacin (8), the first shortened AGE with only a terminal $\gamma$-lactone moiety and an aliphatic chain, was reported in 1991 [48].

Due to the difficulty in crystallising aliphatic AGEs, the determination of the absolute stereochemistry of AGEs became the main challenge of the research work. Hoye et al. first used spectroscopic methodologies to determine the absolute configurations of stereogenic carbinol centres in the five adjacent bis-THF AGEs and four mono-THF AGEs with the refined Mosher method in $1992[43,44]$. They also validated the configuration at the C-4 carbinol centre in these bioactive AGEs as the $R$ configuration [49].

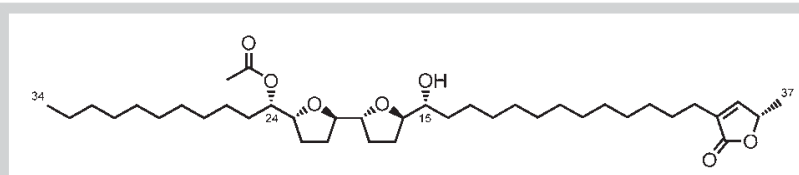

uvaricin (1)

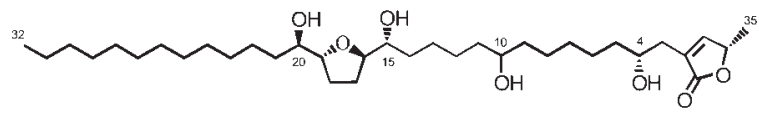

annonacin (2)

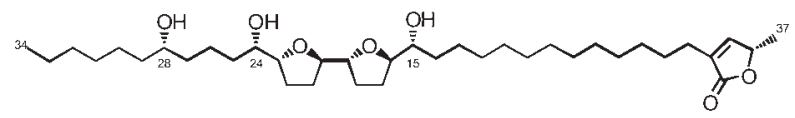

squamocin (3)

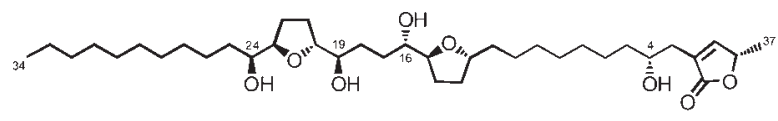

bullatalicin (4)

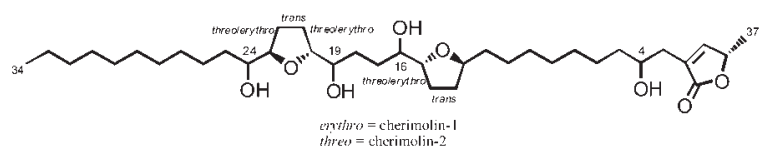

cherimoline (5)

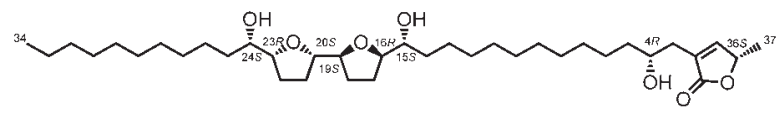

revised rolliniastatin $1(6)$

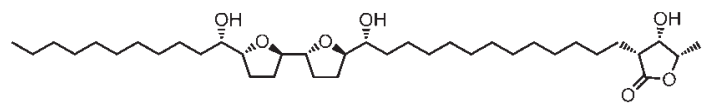

laherradurine (7)

Fig. 1 Structures 1-7.

Fujimoto et al. designed a series of mono-THF compounds with various conformations and reported their ${ }^{13} \mathrm{C}-\mathrm{NMR}$ resonances, which are useful in determining the conformations of the THF ring moieties [50]. Yu et al. made a single crystal of (+)-gigantecin (9) from A. coriacea Mart for an X-ray study to determine its absolute conformation [51]. These research findings accelerated the process for the structural identification of the AGEs.

On the other hand, Duret et al. suspected that AGEs with terminal ketolactones (isoforms) were artefacts of the translactonisation of 4-hydroxy-AGEs. They further confirmed this hypothesis by performing the extraction and characterisation of the initial AGEs from fresh crude materials under the effects of alkaloids, basic media, and alcohols. These reagents affected the kinetics of the translactonisation [52], a result that was later supported by Duret et al work showing that 4-hydroxylated AGEs led to isoAGEs under basic conditions [53].

The studies on AGEs in the modern stage (from 1996 to 2000) were concerned with the efficient identification of AGEs by hyphenated techniques and other spectroscopic methods. Although normal and reverse-phase HPLC are powerful tools for the isolation of natural products, they still have some limitations, such as the amount of sample that can be purified per unit time, the cost of the solvent, the size of the columns. Searching for new technologies to facilitate the chromatographic work is very important. Hopp et al. used countercurrent chromatography (CCC) to isolate 


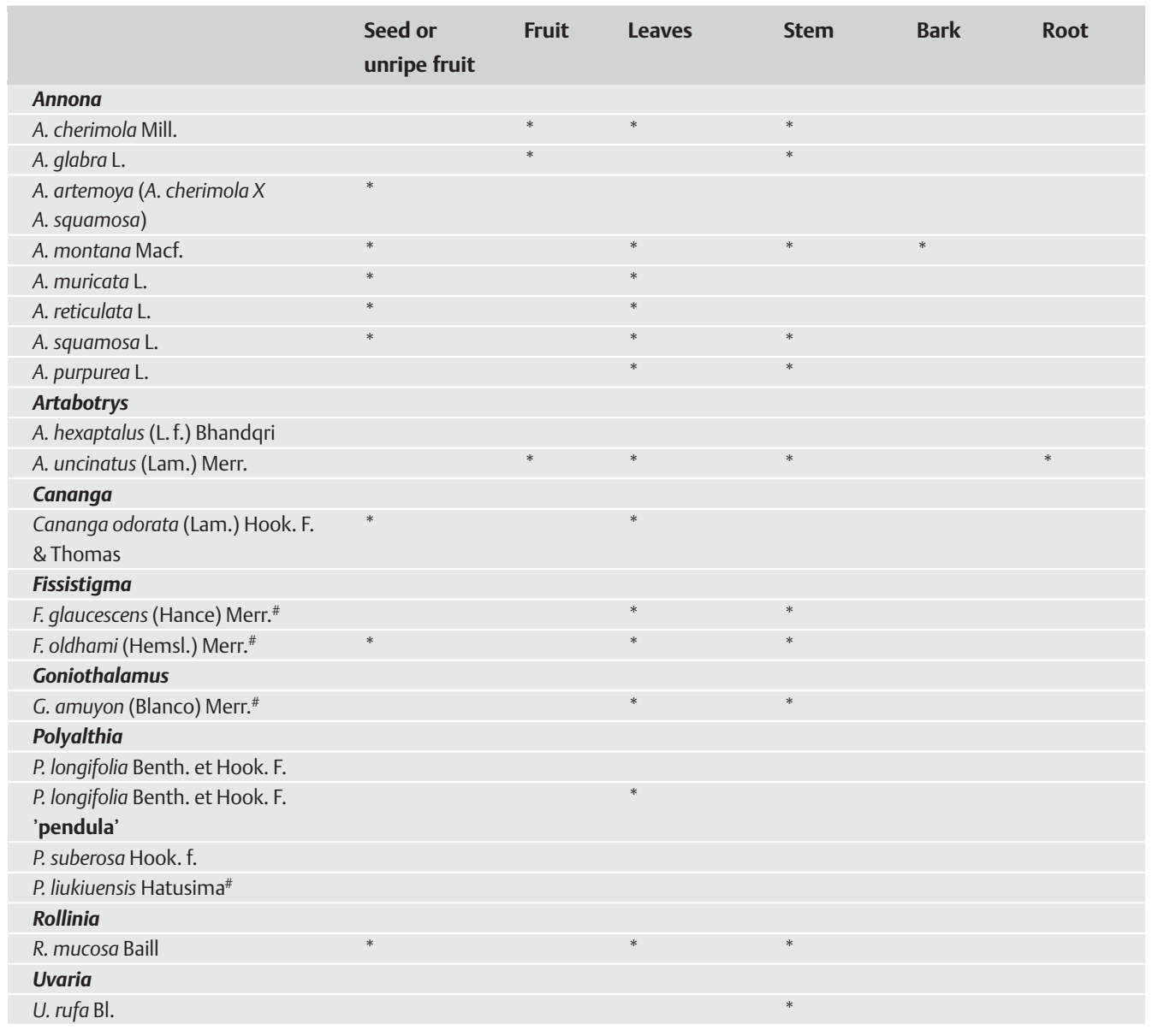

* Chemical components of the material have been studied in our laboratory. ${ }^{*}$ Annonaceous plants that are native in Taiwan island

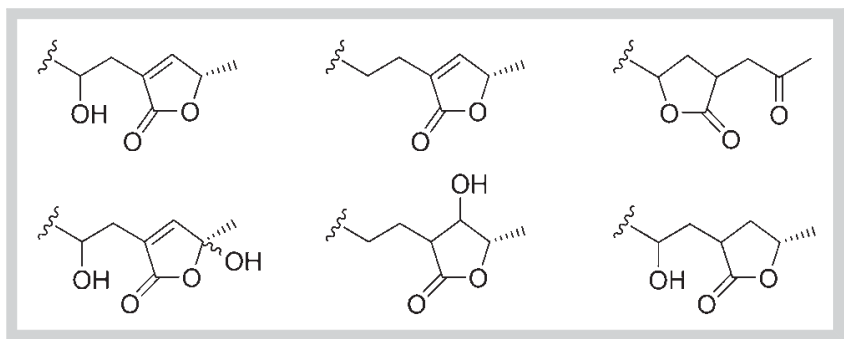

Fig. $2 y$-Lactone subunits in AGEs.

four AGEs, (2,4-cis- and trans)-9-hydroxyasimicinone (10), (2,4cis- and trans)-squamoxinone B (11), (2,4-cis- and trans)-squamoxinone $C(12)$, and isoannoreticuin (13), from the bark of A. squamosa [54]. Duret et al. also applied high-speed countercurrent chromatography (HSCCC) to the separation of AGEs from A. atemoya to give two major AGEs, squamocin (3) and bullatacin (rolliniastatin-2, 14), and six other known AGEs [55]. Moreover, to separate mixtures of AGEs that cannot be easily purified by regular HPLC methods, some Japanese scholars and our laboratory introduced the recycle-HPLC system for isolating AGEs.

To develop a convenient spectral methodology to determine the stereochemistry of AGEs, Gawronski an Wu provided a far more reliable way of determining the absolute configuration of the $\gamma$ lactone ring moiety through the analysis of the CD spectra of butenolides [25]. Duret et al. modified the Mosher method and de- termined the stereochemistry of asimicin (15) by the long-range anisotropic effect of 2-NMA (naphthylmethoxyacetic acid), [56] (० Fig. 4).

The other key tool for determining the structures of AGEs is mass spectrometry (MS). Generally, electron-impact mass spectrometry (EI-MS) is the preferred technique for determining the placement of the tetrahydrofuran rings and functional groups (hydroxy, ketone, acetoxy and double bond) along the hydrocarbon chain. The derivatised AGEs, such as TMS and acetyl derivatives, are helpful in the elucidation of these structures. In addition, the direct-inlet probe technique (DIP) and lower evaporator energy (e.g., $30 \mathrm{eV}$ ) have been suggested for use with EI-MS scanning because AGEs easily decompose thermally. The structure of squamocin (3) from A. squamosa was characterised by a combination of chemical derivatisation and precursor-ion scanning mass spectrometry. The lactone portion of squamocin (3) was modified with $\mathrm{N}, \mathrm{N}$-dimethylethylenediamine in the vapour phase to afford a strong positive charge at one end of the skeleton [57]. In 1997, $\mathrm{Gu}$ et al. (XenoBiotic Laboratories), cooperating with the McLaughlin group, analysed AGEs from $R$. mucosa that were amenable to liquid chromatography/mass spectrometry (LC/MS) with ionisation source-atmospheric pressure in-source collision-induced dissociation (APICID) to detect the presence of 40 known AGEs, in addition to four new AGEs of diverse structures, in a bioactive crude methanol-soluble fraction from this plant extract [58]. They also observed a unique fragmentation rule for AGEs with a hydroxy group at C-4, which had a characteristic loss of a terminal $\gamma$-lactone (112 amu) during ESI-MS scanning [58]. This 


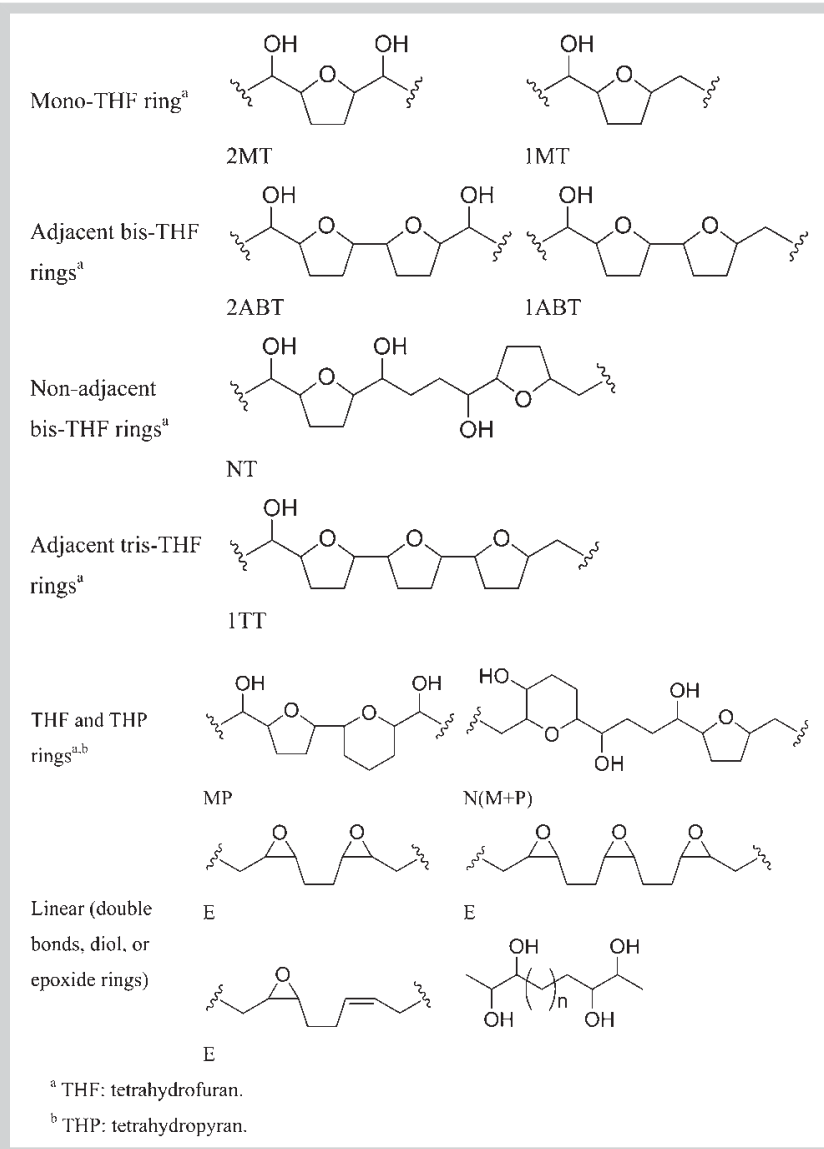

Fig. 3 Tetrahydrofuran (THF), tetrahydropyran (THP), and other oxygenbearing subunits in Annonaceous AGEs.

rapid and relatively uncomplicated selective ionisation procedure also provided a convenient and useful method for identifying AGEs with or without a hydroxy group at C-4.

\section{The Extensive Studies on AGEs after 2000 $\nabla$}

After 2000, we continued investigating the AGEs from Formosan plants of Annona species [59-62]. Among them, two epimeric AGEs, muricins A (16) and B (17) [59], were isolated and their absolute configurations were determined by the modified Mosher method. Muricin B (17) is the first Annonaceous acetogenin to possess a hydroxy group with the $S$-configuration at C-4, where the typical configuration of the hydroxy group was $R$. In 2003, we reported a novel skeleton of abridged AGE, rollicosin (18), from the unripe fruits of Rollinia mucosa Baill, which was the first identified compound that contained lactone moieties on both sides of an aliphatic chain [62]. Soon after this isolation, Chinese scholars reported the second abridged AGE, squamostolide (19), from A. squamosa [63] (๑ Fig. 5).

During this time, the function and mechanism of action of AGEs were investigated. The link between the mitochondrial respiratory chain and cell apoptosis was clarified [64]. The latter, namely programmed cell death, is a normal physiological process that selectively and desirably destroys cells and tissues without an inflammatory response, as opposed to a necrotic cell death. Instead of focusing on the inhibition of mitochondria complex I, we found

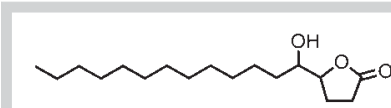

$(-)$-muricatacin $(8)$<smiles></smiles>

(+)-gigantecin (9)

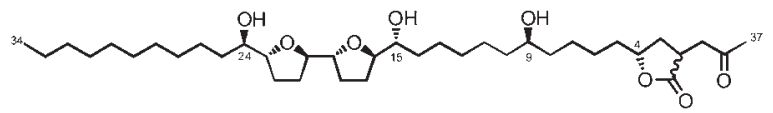

(2,4-cis and trans)-9-hydroxyasimicinone (10)

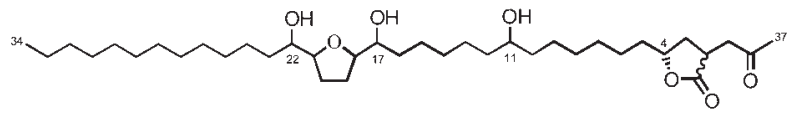

(2,4-cis and trans)-squamoxinone B (11)

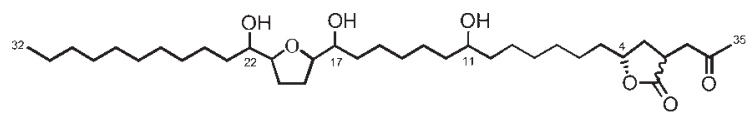

(2,4-cis and trans) squamoxinone C (12)

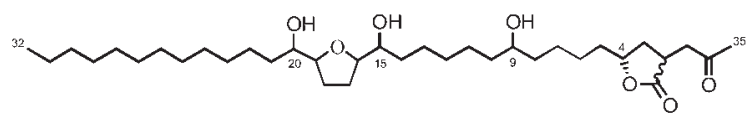

isoannoreticuin (13)

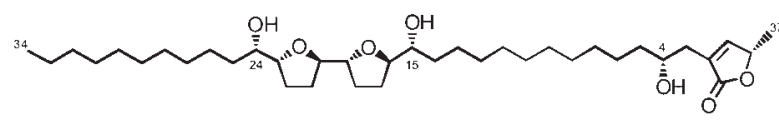

bullatacin (14)

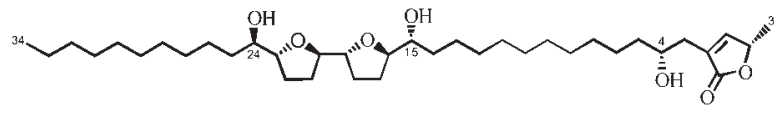

$\operatorname{asimicin}(\mathbf{1 5})$

Fig. 4 Structures 8-15.

that bullatacin (14) could induce cell death via apoptosis based on an analysis of the morphological changes of bullatacin (14)treated Hep 2.2.15, as determined by double staining with fluorescein isothiocyanate (FITC)-labelled annexin $\mathrm{V}$ and propidium iodide (PI) [65]. This finding also opened a new window for exploring the mechanism of action of AGEs. Herein, we summarise the studies on the cytotoxicity and pesticidal activity of AGEs in the last decade.

\section{Biological activities and the mechanisms of action of the AGEs}

Although AGEs were reported with high potential and diverse biological activities, including antibacterial [66], insecticidal, cytotoxic and immunosuppressive effects, pharmaceutical scientists were interested in how AGEs worked in cells (what the mechanism of the anticancer action of AGEs is) and whether the compounds could work in vivo. Combined with the traditional uses of the Annonaceous plants in North America and South-East Asia, scientists noticed the pesticidal activities of AGEs and proposed a possible mechanism of pesticidal action involved to ATP levels in pests. Thereafter, they found that both the cytotoxic and pesticidal activities should be related to ATP generation and NADH oxi- 


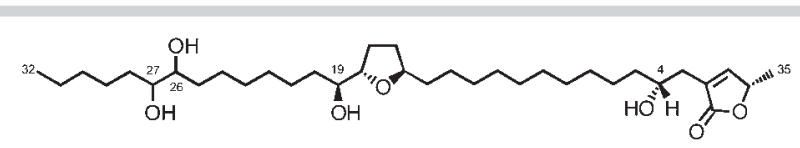

muricin A (16)

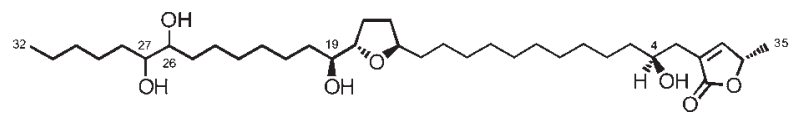

muricin B (17)

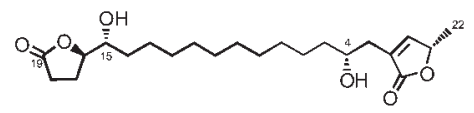

rollicosin (18)

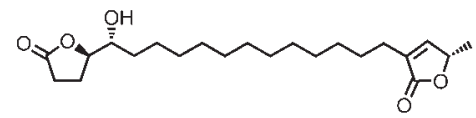

squamostolide (19)

Fig. 5 Structures 16-19.

dation in mitochondria, which directed many ongoing studies about the interaction of AGEs with the mitochondrial complex I.

Anticancer activity: Jolad et al. first reported the significant in vivo cytotoxic activity of uvaricin (1) by the PS screening system [14]. Ahammadsahib et al. used normal mice bearing L1210 murine leukaemia and athymic mice bearing A2780 conventional ovarian cancer xenografts to study the cytotoxic action of bullatacin (14) and analogues in 1993; meanwhile these compounds also have potential as insecticides in insect-derived Sf9 cells. The toxicity of AGEs in both cases probably arises from the strong inhibitory ability of mitochondrial electron transport with specific action at complex I [67]. Degli Esposti et al. (France) first used mammalian mitochondria to study the action of AGEs toward the NADH-ubiquinone reductase (complex I) and reported that bullatacin (14) inhibited the proton pumping function of complex I with similar efficiency under steady-state and nonsteady-state conditions, as compared to the action of rotenone and piericidin [68]. Because of the ability to inhibit the mitochondrial complex I, the main gate of the energy production in the cells, AGEs have been regarded as candidates for future generations of antitumour drugs with different mechanisms.

Besides blocking the NADH: ubiquinone oxidoreductase (complex I) in the electron transport system, AGEs are also powerful inhibitors of the NADH oxidases peculiar to the plasma membranes of cancer cells. Both mechanisms of action result in the inhibition of ATP production and may account for the observation that AGEs are more effective at killing multiple-drug resistant (MDR) tumours than their nonresistant counterparts since the MDR pumps on the cell membranes require ATP to function. In addition, Oberlies et al. observed that AGEs could selectively inhibit the cell growth of cancerous cells by in vitro cell inhibition assays against three murine (P388, PO3, and M17/Adr) and two human (H8 and H125) cancer cell lines [69]. Interestingly, the work of Oberlies et al. proposed that this class of natural products showed a certain biological activity against some drug-resistant cancers. Currently, multidrug-resistant cancers are hard to cure because the cancer cells have developed a mechanism to overcome the anticancer agents. Based on the biochemical differences between MDR and parental cancer cells, such as the ATP-depen- dent P-glycoprotein-mediated pumps (P-gp) and the higher demand for ATP in the MDR cancer cells, Oberlies et al. used bullatacin (14) to test two cell lines, MDR human mammary adenocarcinoma (MCF-7/Adr) cells and the parental, nonresistant wildtype (MCF-7/wt) cells [70]. Therefore, ATP depletion could be another mode of action of AGEs that offers a special advantage in the chemotherapeutic treatment of MDR tumours.

Shimada et al. also proposed a model for explaining the action of AGEs [71]. They suspected that the lactone ring alone could directly interact with the binding to complex I, and the THF rings with flanking $\mathrm{OH}$ groups function just as hydrophilic anchors at the membrane surface that allow lateral diffusion (or random distribution) of the lactone ring in the membrane interior. To verify the model, Kuwabara et al. synthesised a series of analogues with two terminal $\gamma$-lactone rings [72]. However, the bioassay results did not show that these analogues worked twice as well as AGEs did.

To clarify the mechanism of action of AGEs, we cooperated with biochemists and pharmacologists in Taiwan due to its abundant amount of naturally occurring Formosan AGEs. Yuan et al. found that annonacin ( 2 ) could arrest T24 bladder cancer cells at the G1 phase and cause cytotoxicity in a Bax- and caspase-3-related pathway [73]. In addition, squamocin (3) was also observed to arrest the same cancer cells at the G1 phase and cause a selective cytotoxicity in S-phase-enriched T24 cells via the same pathway of cleaving the functional protein of PARP and inducing cell apoptosis [74]. Squamocin (3) was also found to inhibit the proliferation of $\mathrm{K} 562$ cells via G2/M arrest in association with the induction of p21, p27 and the reduction of Cdk1 and Cdc25C kinase activities [75]. These works connected the AGEs with cell apoptosis, which exploited the multiple functions of AGEs as new anticancer candidates.

Pesticidal activity: Following the North American folk use of Annonaceous plants as pesticides, Rupprecht et al. first noted this application. They determined the pesticidal potencies of the extracts from the paw paw tree (Asimina triloba) by the brine shrimp test (Artemia salina larvae), which paralleled the significant activities seen against the striped cucumber beetle (Acalymma vittatum F.), Mexican bean beetle (Epilachna varivestis Mulsant), mosquito larvae (Aedes aegypti L.), blowfly larvae (Calliphora vicina Meigen), melon aphid (Aphis gossyphii Glover), twospotted-spider mite (Tetranychus urticae Koch) and free-living nematode (Caenorhabditis elegans). During the preliminary screening, asimicin (15) was isolated and its pesticidal action evaluated [76]. Moreover, by the same bioactivity-guided isolation/fractionation method, bullatacin (14) was isolated and its pesticidal effects observed at concentrations as low as $1 \mathrm{ppm}$, whereas bullatacinone (20) lacked pesticidal activities [24]. Meanwhile, Ratnayake et al. conducted a controlled study on the pesticidal potencies of extracts from various plant parts of the paw paw tree (Asimina triloba) using the brine shrimp test [77] (ه Fig. 6).

He et al. further evaluated the pesticidal properties of 44 AGEs using the yellow fever mosquito larvae (YFM) assay [78]. The results clearly demonstrated that most AGEs had pesticidal properties. In addition, they indicated that the adjacent bis-THF AGEs with three hydroxy groups, for example, bullatacin (14) and trilobin (21), were the most potent. They further made AGEs, monoTHF, adjacent bis-THF, and nonadjacent bis-THF types as insecticidal baits to test the potent toxicity of these compounds against insecticide-susceptible and -resistant German cockroaches, compared to the activities of some conventional synthetic insecti- 


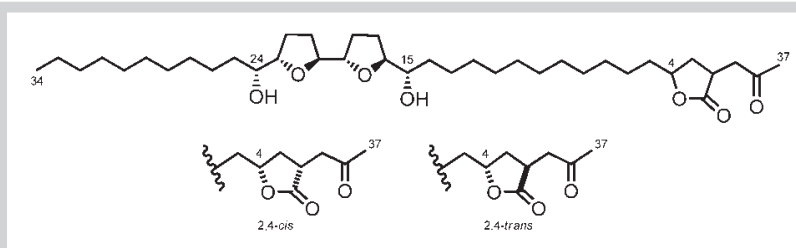

bullatacinone (20)

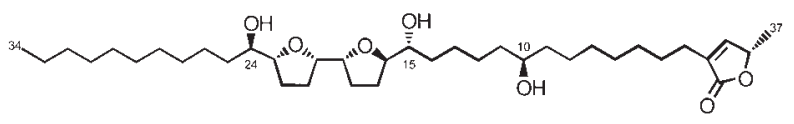

trilobin (21)

Fig. 6 Structures 20-21.

cides [79]. Ohsawa et al. evaluated the insecticidal activities of AGEs from the seeds of the pond apple, A. glabra L. with a micro-sprayer on the cabbage leaf or the filter paper [80]. Meanwhile, Guadano et al. also found that annonacin (2) showed antifeedant effects on $L$. decemlineata and squamocin (3) was toxic to L. decemlineata and $M$. persicae. They also proved that both AGEs were not mutagenic but were toxic in the absence of a metabolic activation system [81].

Londershausen et al. also noticed that extracts of ground seeds from $A$. squamosa revealed interesting insecticidal properties. AGEs were determined to be the active components through an activity-monitored fractionation. The investigation of ATP-levels (at the $\mathrm{LT}_{50}$ value) in Plutella xylostella under treatment with squamocin (3) and antimycin A revealed values of 1.45 and $1.35 \mu \mathrm{mol} / \mathrm{g}$ fresh weight, respectively. Further studies revealed that squamocin (3) showed an inhibitory effect on NADH-cytochrome $c$-reductase and complex I of insect mitochondria with $\mathrm{IC}_{50}$ values of $4-8 \mu \mathrm{mol} / \mathrm{g}$ protein and $0.8 \mu \mathrm{M}$, respectively. Similar results for squamocin (3) were observed for the inhibition of complex I from bovine heart muscle ( $\mathrm{IC}_{50}:<0.1 \mu \mathrm{M}$ ) or Neurospora crassa cells ( $\left.\mathrm{IC}_{50}: 0.3 \mu \mathrm{M}\right)$, but no effects on other coupling sites of mitochondrial complexes were observed [43]. These assembled experimental results were the work of Lewis et al. in 1993 [82]. Friedrich et al. and Hollingworth et al. simultaneously reported the insecticidal action of AGEs to be a result of the inhibition of mitochondria complex I $[83,84]$. Friedrich et al. found that the inhibition of mitochondrial and bacterial NADH: ubiquinone oxidoreductase (complex I) by AGEs was not purely competitive [83]. They demonstrated that AGEs should affect the electron-transfer step from the high-potential iron-sulfur cluster to ubiquinone by directly acting at the ubiquinone-catalytic site of complex I.

\section{The Studies on Modifications and Analogues of the AGEs \\ $\nabla$}

The structure-activity relationship (SAR) studies of AGEs are always interesting for medicinal and natural product chemists. Miyoshi et al. noticed that the alkyl spacer between the $\gamma$-lactone and hydroxylated THF ring moieties elicited potent inhibitory activities on the NADH oxidase [85]. They summarised the SAR rules of AGEs as follows: 1) the adjacent bis-THF ring moiety is not an essential structural factor for inhibition, and the mono-
THF ring compounds can maintain potent activities; 2) this stereochemical factor was also not essential for potent activity irrespective of the number (one or two) of THF rings; 3 ) the THF rings of the AGEs had strong interactions with the interface of lipid bilayers irrespective of the stereochemistry in the THF region; and 4) the spacer moiety is very important for potent activity [86]. Takada et al. also tested the NADH oxidase activity of two naturally occurring AGEs, bullatacin (14) and diepomuricanin (22), and several synthesised analogues in a comparison with that of piericidin A [87]. They concluded that both ring moieties, the $\gamma$ lactone ring and the tetrahydrofuran ring, acted in a cooperative manner on the enzyme and that the optimal length of the alkyl spacer was 13 carbon atoms. These results supported the above hypothesis that Miyoshi et al. offered.

To consider solely the role of the THF ring moieties, Murai et al. synthesised $\triangle$ lac-AGE (23) (AGE without the $\alpha, \beta$-unsaturated $\gamma$ lactone ring), which was also shown to be a novel type of inhibitor that acts at the terminal electron transfer step of mitochondrial NADH-ubiquinone oxidoreductase (complex I). They also synthesised a photolabile $\triangle$ lac-AGE (24) connected to a biotin probe to trace the labelled peptide without the use of a radioisotope. This photolabile $\triangle$ lac-AGE (24) elicited potent inhibition of bovine heart mitochondrial complex I at nanomolar levels [88]. Ichimaru et al. further synthesised a series of $\triangle$ lac-AGEs, in which the stereochemistry around the hydroxylated tetrahydrofuran (THF) ring moiety was systematically modified, and examined their inhibitory effects on complex I. The results revealed that the bis-THF ring analogues are much more potent than the mono-THF ring analogues and that the stereochemistry around the bis-THF ring moiety played a significant role in the inhibitory effects on complex I [89]. Compound 25 showed a similar IC $_{50}$ value as was observed for bullatacin (14) in the reduction of NADH oxidase activity $(0.60-0.65 \mathrm{mmol} \mathrm{NADH} / \mathrm{min} / \mathrm{mg}$ of protein) in submitochondrial particles. Intriguingly, Ichimaru et al. demonstrated that the inhibitory site of complex I on which $\triangle$ lac-AGEs acted might be different from that at which natural AGEs did.

On the other hand, these featured structures, such as the $\gamma$-lactone ring moiety, one to three THF/THP rings with multiple chiral centres, and an alkyl side chain make AGEs difficult and challenging synthetic targets. Because substantial amounts of pure samples are required for further biological and clinical studies, a number of total syntheses of AGEs have been reported in the literature since the 1990s. Recent advances in the total syntheses of AGEs include mono-THF AGEs: murisolin (26) [90,91], longicin (27) [92, 93], and cis-solamin (28) [94,95], adjacent bis-THF AGEs: bullatacin (14) [96], rolliniastatin 1 (7) [23,97], rollimembrin (29) [97,98], 10-hydroxyasimicin (30) [99,100], membranacin (31) [97,101], asimicin (15) [76,102], longimicin D (32) [103-104], and mucoxin (33) [105,106], non-adjacent bis-THF AGEs: cis-sylvaticin (34) [107,108] and gigantecin (9) [109,110], and others, jimenezin (35) [111,112], mucocin (36) [113,114], pyranicin (37) $[115,116]$, pyragonicin (38) $[115,117,118]$, rollicosin (18) $[62,119]$ and squamostolide (19) $[63,120]$ ( Fig. 7).

In addition to the total syntheses of various AGEs, some special analogues were designed to improve the bioactivities through, for example, modifications of the $\gamma$-lactone ring, the THF ring, and hydroxy moieties on the aliphatic chain. 


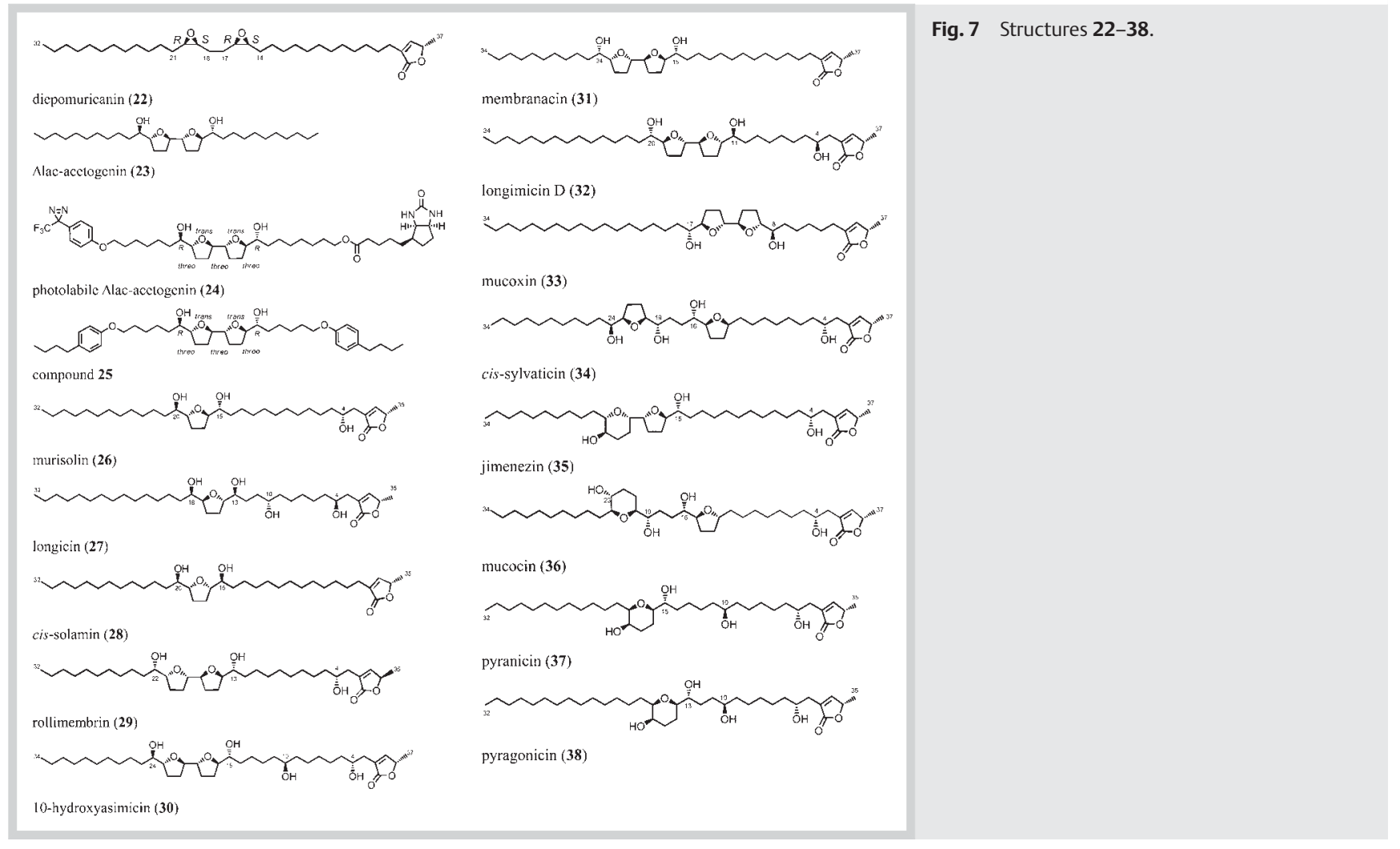

\section{Modifications of the $y$-lactone ring moiety}

Hoppen et al. designed and prepared quinone-mucocin (39) and quinone-squamocin $D(\mathbf{4 0})$ to elucidate the mechanisms of action of the AGEs. The $\mathrm{IC}_{50}$ values of $\mathbf{3 9}$ and $\mathbf{4 0}$ in the inhibition of the mitochondrial NADH-ubiquinone oxidoreductase complex were 3.6 and $1.7 \mathrm{nM}$, respectively [121]. These results supported their hypothesis that AGEs are competitive inhibitors at the ubiquinone binding site of complex I based on the structural similarity between the butenolide and the quinine. Arndt et al. synthesised a systematic variation of featured structures, the butenolide and the ether components, to evaluate the critical factors for the interaction of the AGEs with complex I. Their results and data from the smaller substructures indicated that the substructures of the AGEs, the polyether component and the lipophilic side chain, would be necessary for strong binding of the AGEs to complex I [122].

In addition, aromatic heterocycles are commonly found as base structures of potent complex I inhibitors. Duval et al. tried to replace the $\alpha, \beta$ unsaturated $\gamma$-lactone moiety of squamocin (3) with benzimidazole via an unusual condensation-oxidative decarboxylation reaction with 1,2-diamines in the presence of acetic acid and oxygen. Although they did not clarify the inhibitory ability of the modified squamocin toward complex I, one of the benzimidazole analogues (41) showed cytotoxicity (KB 3-1) with an $\mathrm{IC}_{50}$ value of $2.2 \times 10^{-3} \mu \mathrm{M}$ and induced a $61 \%$ accumulation of the G1 phase of the KB 3-1 cell cycle at concentrations of 1-5 nM, with apoptosis above $10 \mathrm{nM}$ [123]. In 2006, Duval et al. semisynthesised a series of heterocyclic analogues of squamocin (3). Their results suggested that the binding of this hybrid inhibitor (41) was responsible for a negative allosteric effect at the level of the first ubiquinone-binding site of mitochondrial complex I [124].

Duval et al. also prepared a small library of the $\gamma$-keto ester derivatives of squamocin (3) and screened their biological activities, including their cytotoxicity against KB 3-1 cells, inhibition of mitochondrial complex I and of complex III. However, these modified analogues with an open $\gamma$-lactone ring did not show better activity than that of the parent compound, squamocin (3) [125]. Except for the adjacent bis-THF and nonadjacent bis-THF AGEs, Kojima et al. made a series of $\alpha, \beta$-unsaturated- $\gamma$-lactone-free, nitrogen-containing heterocyclic analogues of solamin (42), a mono-THF acetogenin. The cytotoxicities of the compounds were investigated against 39 tumour cell lines. One of them, a 1-methylpyrazol-5-yl derivative (43), showed a selective increase in cytotoxicity against $\mathrm{NCl}-\mathrm{H} 23$ with a potency 80 times higher than that of solamin [126] ( $\odot$ Fig. 8).

\section{Modification of the THF ring moiety}

The AGEs are a large class of naturally occurring polyketides that exhibit potent anticancer activities. In 2000, based on both the difficulty associated with total syntheses of AGEs and the straightforward means by which their structures can be simplified, Chinese and French scholars both proposed to replace the ethylene bridge in the THF rings with normal and iso-terminal lactone moieties, respectively $[127,128]$.

Yao and coworkers further studied simplified AA005 (44) and its analogues, which showed potent antitumour activities and significant selectivity between normal cells and cancer cells $(\geq 7$, [129]). Zeng et al. designed and synthesised (4R)-hydroxylated analogue 45 based on the structure of bullatacin (14). The preliminary screenings showed that the $\mathrm{IC}_{50}$ values of $\mathbf{4 5}$ were $1.6 \times 10^{-3}$ and $8 \times 10^{-2} \mu \mathrm{g} / \mathrm{mL}$ against HT-29 and HCT- 8 cells, respectively. A remarkable enhancement of cytotoxic effect for the $4(R)$-hydroxy analogue (45) was observed [130]. The results support a very interesting piece of information, namely that both the butenolide and ethylene glycol subunits play essential roles in the cytotoxicities of the compounds against tumour cell lines. Their precise 


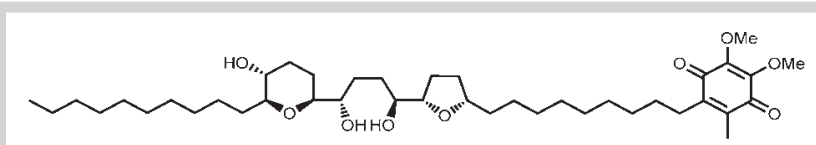

quinone-mucocin (39)

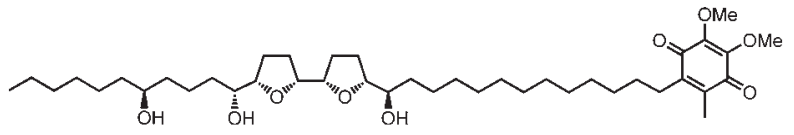

quinone-squamocin D (40)

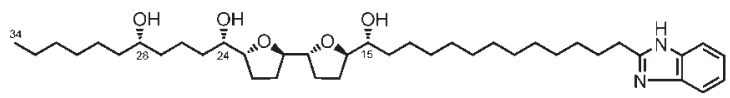

benzomidazole analogues (41)

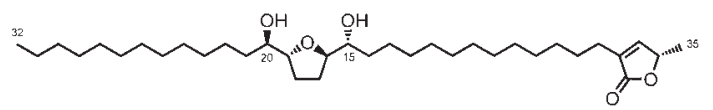

solamin $(\mathbf{4 2})$

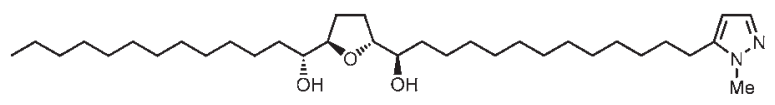

1-methylpyrazol-5-yl derivative (43)

Fig. 8 Structures 39-43.

role is not yet clear. Additionally, the presence of the hydroxy group at C-10 and the absolute configuration of the methyl group on the butenolide moiety (46) are less important for their activity [131].

Rodier et al. tried to introduce a benzoyl group to fix the moiety between the ether linkage; these analogues display interesting cell cycle effects but are less potent than bullatacinone (20), a compound with the same terminal lactone [132]. Fujita et al. also tried to replace the bis-adjacent THF ring by a 1,2-cyclopentanediol bis-ether skeleton to obtain simplified mimics 47-50. Based on the evaluation of the inhibitory effects on mitochondrial NAD$\mathrm{H}$ : ubiquinone oxidoreductase (complex I), the 1,2-cyclopentanediol bis-ether motif also showed very potent inhibitory activity at the nanomolar level [133].

For the study of AGE mimics, Liu et al. further designed, synthesised and evaluated a new series of mimics containing a terminal lactam [134]. They found that the $N$-methylated lactam-containing compounds $\mathbf{5 1 , 5 2}$, and 53 exhibited comparable potencies to that of AA005 (44) and similar selectivity among cancer cells. $N$ Methyl compound $\mathbf{5 1}$ shows comparable activities to that of AA005 (44) and retains similar cell selectivity. It was also revealed that the stereogenic centre on the lactam is not essential for antitumour activity. Recently, Liu et al. synthesised a series of analogues by replacing the acyclic bis-ether functionality of AA005 (44) with certain conformationally constrained fragments. Interestingly, most newly synthesised mimetics were found to exhibit potent activities against breast cancer cells and showed satisfactory selectivities between cancerous and noncancerous cells. Among them, an N,N'-dimethyl bis-amide compound (54) exhibits more potency against MDA-MB-468 cells than does its parent molecule AA005 (44). Studies by Lin et al. indicate that bisamide analogues of AA005 make this unique class of anticancer agents much simpler and allow more flexibility for their future development [135] ( $\odot$ Fig. 9).<smiles>CCCCCCCCCC[C@H](O)COCCOC[C@H](O)CCCCCCCCCCCCC1=CC(C)OC1=O</smiles>

AA005 (44)<smiles>CCCCCCCCCC[C@H](O)COCCOC[C@H](O)CCCCCCCCCC[C@H](O)CC1=C[C@H](C)OC1=O</smiles>

compound 45<smiles>CCCCCCCCCC[C@H](O)COCCOC[C@H](O)CCCC[C@H](O)CCCCCCCC1=C[C@H](C)OC1=O</smiles>

compound 46

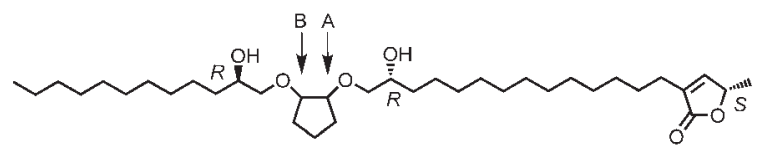

simplified mimics $\mathbf{4 7}-\mathbf{5 0}$

47: A- $R, \mathrm{~B}-R ; 48: \mathrm{A}-R, \mathrm{~B}-S ; 49: \mathrm{A}-S, \mathrm{~B}-R$; 50: A- $S, \mathrm{~B}-S$

$$
\begin{aligned}
& \mathbf{5 1} R_{1}=M e, R_{2}=M e, R_{3}=H \\
& 52 R_{1}=M e, R_{2}=M c, R_{3}=M e \\
& 53 R_{1}=M c, R_{2}=H, R_{3}=H
\end{aligned}
$$

$N$-methylated lactam-containing analogues $51-53$ of AA005.<smiles>CCCCCCCCCC[C@H](O)C(=O)N(C)CCN(C)C(=O)[C@H](O)CCCCCCCCCCCCC1=C[C@H](C)OC1=O</smiles>

$N, N^{\prime}$-dimethyl bis-amide compound (54)

Fig. 9 Structures $\mathbf{4 4 - 5 4 .}$

\section{Replacement of the hydroxy moiety}

\section{on the aliphatic chain}

Some scholars have studied the replacement of the hydroxy moieties on the aliphatic chain of AGEs. Ye et al. obtained halogensubstituted AGEs, 4(S)-chloro-4-deoxygigantetrocin A and 4(S)18-dichloro-4,18-dideoxy-asimilobin, by treating gigantetrocin A with triphenylphosphine and $\mathrm{CCl}_{4}$. The chlorinated compounds showed decreased bioactivities in the brine shrimp lethality test and against human tumour cell lines [136]. Kojima et al. made C4-fluorinated analogue (55) of solamin and evaluated its antitumour activities against 39 tumour cell lines. They found that C4-fluorinated solamin (55) showed more potent growth inhibitory activity against cancer cell lines than did solamin [137].

On the other hand, Gallardo et al. made 10-oximeguanacone (56), the first bioactive nitrogenated acetogenin, which showed potent inhibition towards complex I by the titration of the NADH oxidase and NADH: ubiquinone oxidoreductase activities [138]. Duret et al. semisynthesised amino derivatives from two natural AGEs, rolliniastatin-1 and squamocin. Although it is noteworthy that these amino-AGEs still retain some activity, more studies are required to confirm the potencies of these derivatives as new specific and efficient anticancer agents [139].

A variety of chemical strategies has been applied to investigating biological processes. Recently, fluorescent modifications became powerful tools for visualising the distribution of bioactive natural 
products in cells and investigating their targeting. In 2005, Derbre et al. synthesised hybrids consisting of an AGE tail connected to a fluorescent tag. Using fluorescent microscopy, both 57 and 58 were initially observed in Jurkat cell mitochondria, but they diffused into the cytosol of apoptotic cells, supporting the conclusion that squamocin (3) passes through the plasma membrane and targets the mitochondria. Indeed, both semisynthesised fluorescent derivatives were shown to be potent apoptosis inducers that were directed to this organelle. Besides, they proposed that the lactone moiety seems not to interfere with the mitochondrial targeting but apparently influenced the bioactivity of AGEs [140]. Alexander et al. attached ethyl 7-dimethylaminocoumarin 4-acetate to the diols of (-)-mucocin (59) through amide coupling chemistry. Although coumarin-labelled mucocin can also induce fluorescently coded morphogenic responses, no expected response was found [141]. This result might be due to the occupation of the mitochondrial recognition site by the fluorescent coumarin group. To overcome the above disadvantage, Maezaki et al. and Kojima et al. labelled the terminal aliphatic chain of solamin $(\mathbf{6 0}, \mathbf{6 1})$ with fluorescent groups, 7-nitrobenzo [c][1,2,5]oxadiazol-4-yl-amino (NBD-NH-) and 5-dimethylaminonaphthalen-1-yl-sulfonamide (dansyl-NH-), in 2007 and 2009 , respectively $[142,143]$. It was anticipated that these compounds would be used to explore the targeting of AGEs.

Among AGE mimics, Liu et al. tried to modify the C-10 hydroxy group of the AGE mimic to introduce a label based on the results of the anticancer-activity screenings of parallel synthetic analogues. Fluorescent-imaging studies revealed that AA005-flu's (62 and 63) distribution in normal human cells was significantly different from that in cancer cells. AA005-flu accumulated in the mitochondria of the cancer cells. This direct and visible evidence suggests that membrane recognition of AA005 (44) is involved in its selective bioactivity [144] (๑ Fig. 10).

\section{AGEs as cation ionophores}

Although many research results mentioned the mechanisms of AGEs, for instance, the inhibitory action of mitochondria complex I (NADH: ubiquinone oxidoreductase) [145], induction of programmed cell death by the expression of the pro-apoptotic proteins Bax, Bad, caspase-3 [74] and the structure-activity relationships of either natural, semisynthesised or synthesised compounds, the diverse bioactivities of the various types of AGEs still seem difficult to explain. Some researchers notice the chemophysical features of various AGEs and more direct evidence was provided as a new structure-activity relationship for AGEs.

Sasaki et al. first reported the ionophore activity of the AGEs. It was revealed by NMR studies that the structurally-related analogues of AGEs form supramolecular complexes with metal cations [146]. These studies indicated that hydroxylated bis-THF derivatives, structural components of the potent antitumour AGEs, formed supramolecular complexes with metal cations. In particular, some formed $2: 1$ ligand: metal complexes with calcium cations with high selectivity [146]. Although Araya et al. evaluated the ion-transport and ion-binding activities of AGEs using apparatus W-08 in 1995 and did not find any special activity [147], in1998 Sasaki et al. indicated that two AGEs, bullatacin (14) and asimicin (15), and their structurally related analogues binding bivalent cations such as $\mathrm{Ca}^{2+}$ and $\mathrm{Mg}^{2+}[148,149]$. Peyrat et al. evaluated the ${ }^{13} \mathrm{C}$-NMR longitudinal relaxation times $\left(\mathrm{T}_{1}\right)$ of both annonacin (2) and squamocin (3) in the absence and presence of $\mathrm{Ca}^{2+}$ ions to assess the structural changes that accompany complexations. They thought that the interesting cytotoxic activities

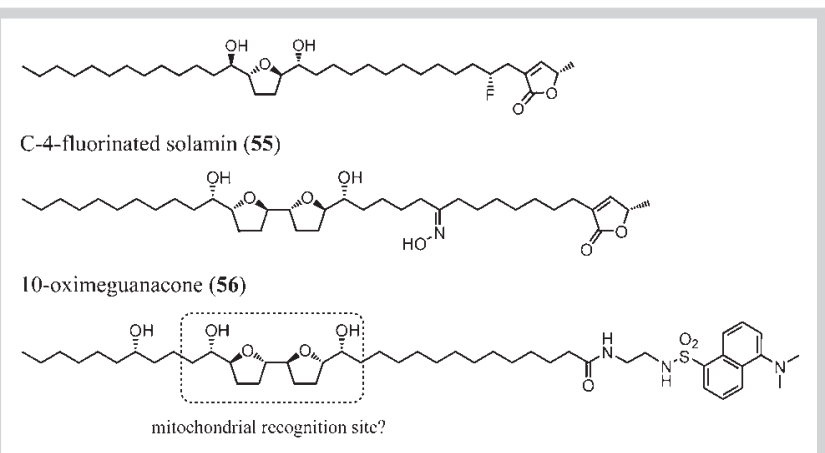

semi-synthesised fluorescent derivative $\mathbf{5 7}$

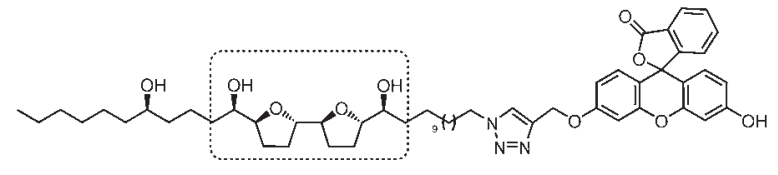

semi-synthesised fluorescent derivative $\mathbf{5 8}$

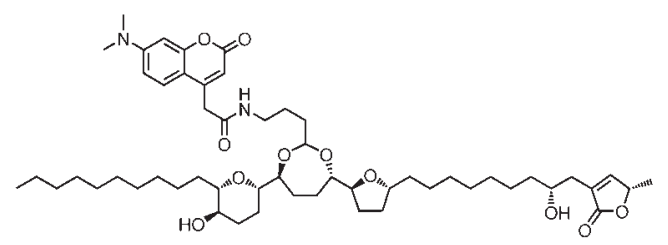

semi-synthesised fluorescent derivative 59

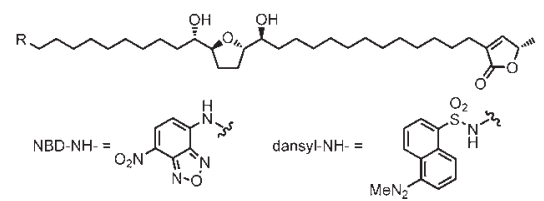

NBD-labelled solamin (60) and dansyl-labelled solamin (61)

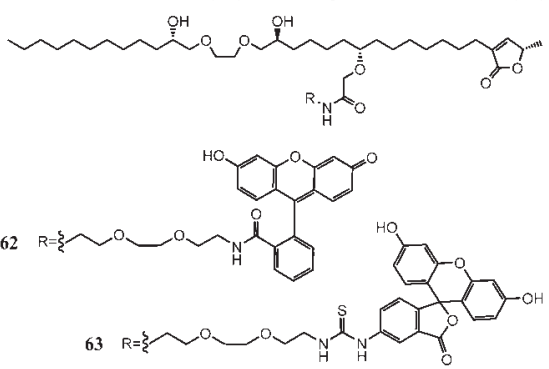

AA005-flus 62 and 63

Fig. 10 Structures 55-63.

of the THF- $\gamma$-lactone derivatives could be explained by their ionophoric ability. Their results also show differences in the stoichiometry of the complexes for mono-THF AGE and bis-THF AGE with $\mathrm{Ca}^{2+}$ ions [150].

In biological studies with living cells, we assumed that AGEs play a role in the bioavailability of the cations in the cell membranes due to their amphiphilic nature. While culturing smooth muscle cells of the human coronary artery with squamocin (3) in our study, we observed that squamocin (3) (an adjacent bis-THF acetogenin) could induce a transient but strong increase in the large-conductance $\mathrm{Ca}^{2+}$-activated $\mathrm{K}^{+}$channels [151]. In a whole-cell configuration, squamocin $(3,0.3-100 \mu \mathrm{M})$ induced a $\mathrm{Ca}^{2+}$-activated $\mathrm{K}^{+}$current $\left[\mathrm{I}_{\mathrm{K}(\mathrm{Ca})}\right]$ in a concentration-dependent manner with an $\mathrm{EC}_{50}$ value of $4 \mu \mathrm{M}$. When cells were exposed to a $\mathrm{Ca}^{2+}$-free solution, squamocin $(3,3 \mu \mathrm{M})$ induced a transient increase in $\mathrm{I}_{\mathrm{K}(\mathrm{Ca})}$. In the continued presence of squamocin (3), an additional increase in ex- 


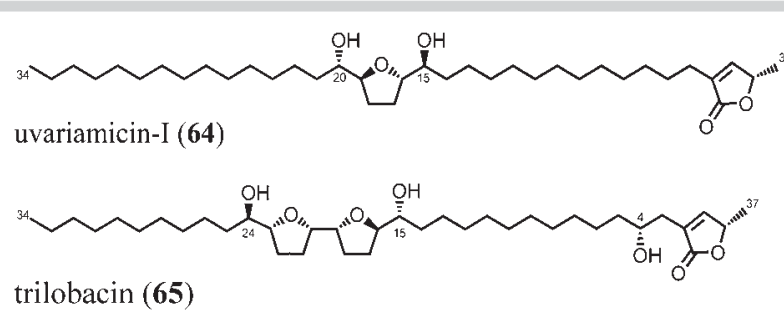

Fig. 11 Structures 64 and 65 .

tracellular $\mathrm{Ca}^{2+}(1 \mathrm{mM})$ caused a significant increase in $\mathrm{I}_{\mathrm{K}(\mathrm{Ca})}$. In the cell-attached configuration of the single-channel recordings, squamocin (3) applied to the bath increased the activity of largeconductance $\mathrm{Ca}^{2+}$-activated $\mathrm{K}^{+}\left(\mathrm{BK}_{\mathrm{Ca}}\right)$ channels without altering the single-channel conductance. These findings provide evidence that squamocin (3) can activate $\mathrm{I}_{\mathrm{K}(\mathrm{Ca})}$ in coronary arterial smooth muscle cells. The initial transient activation of $\mathrm{I}_{\mathrm{K}(\mathrm{Ca})}$ may reflect squamocin-induced $\mathrm{Ca}^{2+}$ release from intracellular $\mathrm{Ca}^{2+}$ stores, whereas the sustained activation of $\mathrm{I}_{\mathrm{K}(\mathrm{Ca})}$ may arise from the squamocin-induced $\mathrm{Ca}^{2+}$ influx across the cell membrane. The stimulatory effects of squamocin (3) on these channels should affect the functional activity of vascular smooth muscle cells [151].

We speculate that AGEs could use their hydrophilic centres (THF rings with flanking hydroxy groups) to bind cations like $\mathrm{Ca}^{2+}$ and surround the ion core by its peripheral hydrophobic regions (long chains). This arrangement allows the molecules to dissolve effectively in the membrane and diffuse transversely into cells as ionophores. We clarified the interaction between mono-THF AGEs and $\mathrm{Ca}^{2+}$ by isothermal titration calorimetry (ITC), which is an extremely powerful and highly sensitive technique for measuring the heats of interaction of reacting species in dilute solution. Interestingly, we found that the mono-THF AGEs annonacin (2) and uvariamicin-I (64) interacted with $\mathrm{Ca}^{2+}$ by an exothermic process, indicating the formation of AGE-calcium complexes [152] (O Fig. 11).

\section{From the Chemical Bench to Preclinical Trials} $\nabla$

In 1976, Ratnayake et al. found that extracts of the leaves and twigs of the native paw paw tree, Asimina triloba, were bioactive in the antitumour screens of the U.S. National Cancer Institute (NCI). Following the sound phytochemical studies on AGEs [77], Gu et al. used the three most active AGEs, bullatacin (14), asimicin (15) and trilobacin (65), to establish quality control over AGE extracts of the paw paw tree by LC/MS/MS [153]. In this study they identified that small twigs from the months of May and June were the optimum plant sources for the commercial harvest of biomass for extraction. They further tried to develop some useful commercial products containing the AGEs, including head lice shampoo (in 2001), ointment, lotion, spray for plant pests, and paw paw capsules (in 2003) for human administration. The entire process from the safety and toxicology of the AGEs to the success of commercial products was described in McLaughlin's 2008 review [154]. More recently, Cuendet et al. reported the potential of the standardised extract from the twigs of A. triloba to mediate a cancer chemopreventative effect in the $\mathrm{N}$-methyl- $\mathrm{N}$-nitrosoureainduced mammary carcinogenesis model. As McLaughlin et al. did, they used three potent bioactive AGEs, bullatacin (14), asimi- cin (15), and trilobacin (65), in their standardised extract. Mammary tumour latency was increased from 55 to 66 days in Sprague-Dawley rats given a diet containing paw paw extract (1250 and $2500 \mathrm{mg} / \mathrm{kg}$ diet; based on maximum tolerated dose studies) [155].

In Taiwan, plants of the genus Annona are important economic crops for their edible fruits. The abundant material obtained from the seeds and the excellent cytotoxicities of the AGEs from this material attracted us to further develop pharmaceutical products. In addition to the aforementioned achievements, oral gavage (PO) animal studies have been performed by MDS Pharma Services and us. The extract from A. muricata, WYC-AA07, was applied to the xenograft tumour model of human MCF-7 breast tumour cells on SCID mice (assay 580000 ). WYC-AA07 at $10 \mathrm{mg}$ / $\mathrm{kg}$ was administered daily by PO for a total of 10 doses. The tumour size, body weight and signs of overt animal toxicities after dosing were monitored and recorded for 25 days. WYC-AA07 at $10 \mathrm{mg} / \mathrm{kg}$ PO caused a significant decrease in the tumour weights from day 13 to day 25. However, it also caused a significant decrease in body weight on days $9,13,17$, and 21 . The other experiment was done on the xenograft tumour model of human HT-29 colon tumours on SCID mice (assay 580100). WYC-AA07 at $20 \mathrm{mg} / \mathrm{kg}$ PO caused death in one half of the animals and a significant decrease in body weight on day 8. Recently, we tested the toxicity of squamocin (3) on nude mice at $20 \mathrm{mg} / \mathrm{kg}$ PO. Although most of the animals showed an abnormal neuron function that caused the mice to move uncontrollably in a lateral direction, the mice recovered after we stopped the administration of squamocin (3). On the other hand, a ethnopharmacological investigation reported the similar side effect of AGEs that a neurodegenerative tauopathy endemic to the Caribbean island of Guadeloupe was suspected to be linked to the consumption of Annonaceous plants. Escobar-Khondiker et al. further found that annonacin (2) induced the retrograde transport of mitochondria to decrease ATP levels, which induces changes in the intracellular distribution of tau in a way that shares characteristics with some neurodegenerative diseases [156]. The possible adverse effect of AGEs on neuron cells should be a concern in advanced pharmaceutical applications for alternative therapy.

\section{Perspectives \\ $\nabla$}

The AGEs are one of the most interesting classes of natural products appearing in the past two decades. They exhibit a wide variety of biological activities, and, impressively, some of them have comparable cytotoxic to taxol against various cancer cells. Both featured structures, the hydroxylated THF and $\gamma$-lactone ring moieties, are thought to be the pharmacophores that block the electron transport system of mitochondrial complex I. Much effort has been dedicated to elucidating the underlying cytotoxic mechanisms of the AGEs and to synthesising AGE analogues by altering the spacing between two moieties, removing either one of two critical featured structures ( $\triangle$ Lac AGEs or muricatacin), or mimicking the THF rings by ether linkages. Although none of the modified AGEs obtained thus far have demonstrated activities comparable to those of the naturally occurring AGEs, studies on the synthesis and mechanisms of action of these compounds established solid fundamental knowledge and drug discovery experience. For example, the studies on analogues of AGEs created a series of compounds that contain completely different skeletons, of which some also show excellent bioactivities against various can- 
cer cells. In addition, in vivo tests in mice showed the antitumour effects and even some possible adverse effects of AGEs. However, there was no released data about the in vivo pharmacokinetic study of AGEs. Thus, more in vivo studies are necessary. Combined with the above information, it will be substantially helpful to further develop these types of compounds as new drugs.

\section{References}

1 Cragg GM, Newman DJ, Snader KM. Natural products in drug discovery and development. J Nat Prod 1997; 60: 52-60

2 Wani MC, Taylor HL, Wall ME, Coggon P, McPhail AT. Plant antitumor agents. VI. Isolation and structure of taxol, a novel antileukemic and antitumor agent from Taxus brevifolia. J Am Chem Soc 1971; 93: 2325-2327

3 Wall ME, Wani MC, Cook CE, Palmer KH, McPhail AT, Sim GA. Plant antitumor agents. I. The isolation and structure of camptothecin, a novel alkaloidal leukemia and tumor inhibitor from Camptotheca acuminata. J Am Chem Soc 1966; 88: 3888-3890

4 Hartwell JL, Schrecker AW. Components of podophyllin. V. The constitution of podophyllotoxin. J Am Chem Soc 1951; 73: 2909-2916

5 Neuss N, Gorman M, Hargrove W, Cone NJ, Biemann K, Buechi G, Manning RE. Vinca alkaloids. XXI. The structures of the oncolytic alkaloids vinblastine (VLB) and vincristine (VCR). J Am Chem Soc 1964; 86: 1440-1442

6 Arcamone F, Franceschi G, Penco S, Selva A. Adriamycin (14-hydroxydaunomycin), a novel antitumor antibiotic. Tetrahedron Lett 1969; 13: $1007-1010$

7 Rupprecht JK, Hui YH, McLaughlin JL. Annonaceous acetogenins: a review. J Nat Prod 1990; 53: 237-278

8 Zeng L, Ye Q Oberlies H, Shi G, Gu ZM, He K, McLaughlin JL. Recent advances in annonaceous acetogenins. Nat Prod Rep 1996; 13: 275-306

9 Cave A, Figadere B, Laurens A, Cortes D. Acetogenins from Annonaceae. Progress in the chemistry of organic natural products, vol. 70. Berlin, Heidelberg: Springer Publisher; 1997: 81-288

10 Bermejo A, Figadere B, Zafra-Polo MC, Barrachina I, Estornell E, Cortes D. Acetogenins from Annonaceae. Recent progress in isolation, synthesis, and mechanisms of action. Nat Prod Rep 2005; 22: 263-303

11 Leboeuf M, Cave A, Bhaumik PK, Mukherjee B, Mukherjee R. The phytochemistry of the Annonaceae. Phytochemistry 1982; 21: 2783-2813

$12 W u$ YC. New research and development on the Formosan annonaceous plants. In: Atta-ur-Rahman, editor. Studies in natural products chemistry, vol. 33. Amsterdam: Elsevier B.V.; 2006: 957-1024

13 Nakanishi Y, Chang FR, Liaw CC, Wu YC, Bastow KF, Lee KH. Acetogenins as selective inhibitors of the human ovarian $1 \mathrm{~A} 9$ tumor cell line. J Med Chem 2003; 46: 3185-3188

14 Jolad SD, Hoffmann JJ, Schram KH, Cole JR. Uvaricin, a new antitumor agent from Uvaria accuminata (Annonaceae). J Org Chem 1982; 47: 3151-3153

15 McCloud TG, Smith DL, Chang C-J, Cassady JM. Annonacin, a novel, biologically active polyketide from Annona densicoma. Experientia 1987; 43: 947-949

16 Fujimoto Y, Eguchi T, Kakinuma K, Ikekawa N, Sahai M, Gupta YK. Squamocin, a new cytotoxic bis-tetrahydrofuran containing acetogenin from Annona squamosa. Chem Pharm Bull 1988; 36: 4802-4806

17 Hui YH, Rupprecht JK, Anderson JE, Liu YM, Smith DL, Chang CJ, McLaughlin JL. Bullatalicin, a novel bioactive acetogenin from Annona bullata (Annonaceae). Tetrahedron 1989; 45: 6941-6948

18 Cortes D, Rios JL, Villar A, Valverde S. Cherimoline et dihydrocherimoline: deux nouvelles $\gamma$-lactones bis-tetrahydrofuranniques possedant une activite antimicrobienne. Tetrahedron Lett 1984; 25: 3199-3202

19 Cortes D, Myint SH, Dupont B, Davoust D. Acetogenins of the Annonaceae. Part 20. Bioactive acetogenins from seeds of Annona cherimolia. Phytochemistry 1993; 32: 1475-1482

20 Rios JL, Cortes D, Valverde S. Acetogenins, aporphinoids, and azaanthraquinone from Annona cherimolia seeds. Planta Med 1989; 55: 321-323

21 Hoye TR, SuhadolnikJC. On the stereochemistry of the bistetrahydrofuranyl moiety of uvaricin. Proton chemical shifts can play a crucial role in complex structure determination. J Am Chem Soc 1987; 109: 44024403

22 Hoye TR, Zhuang ZP. Validation of the proton NMR chemical shift method for determination of stereochemistry in the bistetrahydrofuranyl moiety of uvaricin-related acetogenins from Annonaceae: rolliniastatin 1 (and asimicin). J Org Chem 1988; 53: 5578-5580
23 Pettit GR, Cragg GM, Polonsky J, Herald DL, Goswami A, Smith CR, Moretti C, Schmidt JM, Weisleder D. Isolation and structure of rolliniastat 1 from the South American tree Rollinia mucosa. Can J Chem 1987; 65: 14331435

24 Hui YH, Rupprecht JK, Liu YM, Anderson JE, Smith DL, Chang CJ, McLaughlin JL. Bullatacin and bullatacinone: two highly potent bioactive acetogenins from Annona bullata. J Nat Prod 1989; 52: 463-477

25 Gawronski J, Wu YC. A note on the determination of absolute configuration of acetogenins by circular dichroism. Polish J Chem 1999; 73: 241-243

26 Born L, Lieb F, Lorentzen JP, Moeschler H, Nonfon M, Soellner R, Wendisch $D$. The relative configuration of acetogenins isolated from Annona squamosa: annonin I (squamocin) and annonin VI. Planta Med 1990; 56: 312-316

27 Hoye TR, Suhadolnik JC. Symmetry-assisted synthesis of triepoxide stereoisomers of E,Z,E-dodeca-2,6,10-trien-1,12-diol and their cascade reactions to 2, 5-linked bistetrahydrofurans. J Am Chem Soc 1985; 107: 5312-5313

28 Huang TS. Flora of Taiwan, vol.2. Taipei: Lungwei Printing Co. Ltd.; 1996: 415-419

29 Liao JC. A list of scientific names of woody plants in Taiwan. Taipei: College of Agriculture, National Taiwan University; 1993

$30 \mathrm{Wu}$ YC, Chang GY, Ko FN, Teng CM. Bioactive constituents from the stems of Annona montana. Planta Med 1995; 61: 146-149

31 Chen KS, Ko FN, Teng CM, Wu YC. Antiplatelet and vasorelaxing actions of some aporphinoids. Planta Med 1996; 62: 133-136

32 Lin CH, Yang CM, Ko FN, Wu YC, Teng CM. Antimuscarinic action of liriodenine, isolated form Fissistigma glaucescens, in canine tracheal smooth muscle. Br J Pharmacol 1994; 113: 1464-1470

33 Chang GJ, Wu MH, Wu YC, Su MJ. Electrophysiological mechanisms for antiarrhythmic efficacy and positive inotropy of liriodenine, a natural aporphine alkaloid from Fissistigma glaucescens. Br J Pharmacol 1996; 118: $1571-1583$

34 Ko FN, Yu SM, Su MJ, Wu YC, Teng CM. Pharmacological activity of (-)-discretamine, a novel vascular $\alpha$-adrenoceptor and 5-hydroxytryptamine receptor antagonist, isolated from Fissistigma glaucescens. Br J Pharmacol 1993; 110: 882-888

35 Wu YC, Chang FR, Duh CY, Wang SK, Wu TS. Cytotoxic styrylpyrrones of Goniothalamus amuyon. Phytochemistry 1992; 31: 2851-2853

36 Wu YC, Duh CY, Chang FR, Chang GY, Wang SK, Chang IJ, McPhail DR, McPhail AT, Lee KH. The crystal structure and cytotoxicity of goniodiol-7-monoacetate from Goniothalamus amuyon. J Nat Prod 1991; 54: 1077-1081

37 Wu YC, Chang FR, Chen KS, Liang SC, Lee MR. Studies on acetogenins from Formosan Annonaceous plants. 3. Diepoxymontin, a novel acetogenin from Annona montana. Heterocycles 1994; 38: 1475-1478

38 Wu YC, Chang FR, Duh CY, Wang SK. Annoreticuin and isoannoreticuin: two new cytotoxic acetogenins from Annona reticulata. Heterocycles 1992; 34: 667-674

39 Chang FR, Wu YC, Duh CY, Wang SK. Studies on the acetogenins of Formosan Annonaceous plants, II. Cytotoxic acetogenins from Annona reticulata. J Nat Prod 1993; 56: 1688-1694

40 Zhang $L$, Yang $R$, Wu X. Chemical compositions of Goniothalamus howi (I). Zhiwu Xuebao 1993; 35: 390-396

41 Yu J, Luo X, Sun L, Liu C, Hong S, Ma L. Squamostatin-B, a new polyketide from Annona squamosa (Annonaceae). Chin Chem Lett 1993; 4: 423426

42 Li CM, Mu Q Hao XJ, Sun HD, Zheng HL, Wu YC. Three new bioactive Annonaceous acetogeninins from Annona muricata. Chin Chem Lett 1994; 5: 747-750

43 Londershausen $M$, Leicht W, Lieb F, Moeschler H, Weiss H. Molecular mode of action of annonins. Pestic Sci 1991; 33: 427-438

44 Gu ZM, Fang XP, Miesbauer LR, Smith DL, McLaughlin JL. 30-, 31-, and 32hydroxybullatacinones: bioactive terminally hydroxylated Annonaceous acetogenins from Annona bullata. J Nat Prod 1993; 56: 870-876

45 Gu ZM, Fang XP, Rieser MJ, Hui YH, Miesbauer LR, Smith DL, Wood KV, McLaughlin JL. New cytotoxic Annonaceous acetogenins: bullatanocin and cis- and trans-bullatanocinone, from Annona bullata (Annonaceae). Tetrahedron 1993; 49: 747-754

46 Gu ZM, Fang XP, Zeng L, Wood KV, McLaughlin JL. Bullacin: a new cytotoxic Annonaceous acetogenin from Annona bullata. Heterocycles 1993; 36: 2221-2228

47 Zafra-Polo MC, Figadere B, Gallardo T, Tormo JR, Cortes D. Natural acetogenins from Annonaceae, synthesis and mechanisms of action. Phytochemistry 1998; 48: 1087-1117 
48 Rieser MJ, Kozlowski JF, Wood KV, McLaughlin JL. Muricatacin: a simple biologically active acetogenin derivative from the seeds of Annona muricata (Annonaceae). Tetrahedron Lett 1991; 32: 1137-1140

49 Rieser MJ, Hui YH, Rupprecht JK, Kozlowski JF, Wood KV, McLaughlin JL, Hanson PR, Zhuang Z, Hoye TR. Determination of absolute configuration of stereogenic carbinol centers in Annonaceous acetogenins by proton and fluorine-19 NMR analysis of Mosher ester derivatives. J Am Chem Soc 1992; 114: 10203-10213

50 Fujimoto Y, Murasaki C, Shimada H, Nishioka S, Kakinuma K, Singh S, Singh M, Gupta YK, Sahai M. Annonaceous acetogenins from the seeds of Annona squamosa. Non-adjacent bis-tetrahydrofuranic acetogenins. Chem Pharm Bull 1994; 42: 1175-1184

51 Yu JG, Hu XE, Ho DK, Bean MF, Stephens RE, Cassady JM, Brinen LS, Clardy J. Absolute stereochemistry of (+)-gigantecin from Annona coriacea (Annonaceae). J Org Chem 2002; 59: 1598-1599

52 Duret P, Laurens A, Hocquemiller R, Cortex D, Cave A. Acetogenins of Annonaceae. 34. Isoacetogenins, artifacts issued from translacationization from annonaceous acetogenins. Heterocycles 1994; 39: 741-749

53 Duret P, Figadere B, Hocquemiller R, Cave A. Epimerization of Annonaceous acetogenins under basic conditions. Tetrahedron Lett 1997; 38 : 8849-8852

54 Hopp DC, Conway WD, McLaughlin JL. Using countercurrent chromatography to assist in the purification of new Annonaceous acetogenins from Annona squamosa. Phytochem Anal 1999; 10: 339-347

55 Duret P, Waechter AI, Margraff R, Foucault A, Hocquemiller R, Cave A. High-speed countercurrent chromatography: a promising method for the separation of the Annonaceous acetogenins. J Liq Chromatogr Relat Technol 1997; 20: 627-635

56 Duret P, Waechter A-I, Figadere B, Hocquemiller R, Cave A. Determination of absolute configurations of carbinols of Annonaceous acetogenins with 2-naphthylmethoxyacetic acid esters. J Org Chem 1998; 63: $4717-4720$

57 Hirayama K, Akashi S, Yuji R, Niitsu U, Fujimoto Y. Structural studies of polyhydroxybis(tetrahydrofuran) acetogenins from Annona squamosa using the combination of chemical derivatization and precursor-ion scanning mass spectrometry. Org Mass Spectrom 1993; 28: 15161524

58 Gu ZM, Zhou D, Wu J, Shi G, Zeng L, McLaughlin JL. Screening for Annonaceous acetogenins in bioactive plant extracts by liquid chromatography/mass spectrometry. J Nat Prod 1997; 60: 242-248

59 Chang FR, Wu YC. Novel cytotoxic Annonaceous acetogenins from Annona muricata. J Nat Prod 2001; 64: 925-931

60 Chang FR, Liaw CC, Lin CY, Chou CJ, Chiu HF, Wu YC. New adjacent bistetrahydrofuran Annonaceous acetogenins from Annona muricata. Planta Med 2003; 69: 241-246

61 Liaw CC, Chang FR, Wu CC, Chen SL, Bastow Kenneth F, Hayashi KI, Nozaki $\mathrm{H}$, Lee $\mathrm{KH}, \mathrm{Wu} Y \mathrm{YC}$. Nine new cytotoxic monotetrahydrofuranic Annonaceous acetogenins from Annona montana. Planta Med 2004; 70: 948-959

62 Liaw CC, Chang FR, Wu MJ, Wu YC. A novel constituent from Rollinia mucosa, rollicosin, and a new approach to develop Annonaceous acetogenins as potential antitumor agents. J Nat Prod 2003; 66: 279-281

63 Xie HH, Wei XY, Wang JD, Liu MF, Yang RZ. A new cytotoxic acetogenin from the seeds of Annona squamosa. Chin Chem Lett 2003; 14: 588590

64 Wolvetang EJ, Johnson KL, Krauer K, Ralph SJ, Linnane AW. Mitochondrial respiratory chain inhibitors induce apoptosis. FEBS Lett 1994; 339: 40-44

65 Chih HW, Chiu HF, Tang KS, Chang FR, Wu YC. Bullatacin, a potent antitumor Annonaceous acetogenin, inhibits proliferation of human hepatocarcinoma cell line 2.2 .15 by apoptosis induction. Life Sci 2001; 69: 1321-1331

66 Cartagena E, Colom OA, Neske A, Valdez JC, Bardon A. Effects of plant lactones on the production of biofilm of Pseudomonas aeruginosa. Chem Pharm Bull 2007; 55: 22-25

67 Ahammadsahib KI, Hollingworth RM, McGovren JP, Hui YH, McLaughlin $J L$. Mode of action of bullatacin: a potent antitumor and pesticidal Anonaceous acetogenin. Life Sci 1993; 53: 1113-1120

68 Degli Esposti M, Ghelli A, Ratta M, Cortes D, Estornell E. Natural substances (acetogenins) from the family Annonaceae are powerful inhibitors of mitochondrial NADH dehydrogenase (complex I). Biochem J 1994; 301: 161-167

69 Oberlies NH, Jones JL, Corbett TH, Fotopoulos SS, McLaughlin JL. Tumor cell growth inhibition by several Anonaceous acetogenins in an in vitro disk diffusion assay. Cancer Lett 1995; 96: 55-62
70 Oberlies NH, Croy VL, Harrison ML, McLaughlin JL. The Anonaceous acetogenin bullatacin is cytotoxic against multidrug-resistant human mammary adenocarcinoma cells. Cancer Lett 1997; 115: 73-79

71 Shimada H, Grutzner JB, Kozlowski JF, McLaughlin JL. Membrane conformations and their relation to cytotoxicity of asimicin and its analogs. Biochemistry 1998; 37: 854-866

72 Kuwabara K, Takada M, Iwata J, Tatsumoto K, Sakamoto K, Iwamura H, Miyoshi $H$. Design syntheses and mitochondrial complex I inhibitory activity of novel acetogenin mimics. Eur J Biochem 2000; 267: 25382546

73 Yuan SSF, Chang HL, Chen HW, Yeh YT, Kao YH, Lin KH, Wu YC, Su JH. Annonacin, a mono-tetrahydrofuran acetogenin, arrests cancer cells at the G1 phase and causes cytotoxicity in a Bax- and caspase-3-related pathway. Life Sci 2003; 72: 2853-2861

74 Yuan SSF, Chang HL, Chen HW, Kuo FC, Liaw CC, Su JH, Wu YC. Selective cytotoxicity of squamocin on T24 bladder cancer cells at the S-phase via a Bax-, Bad-, and caspase-3-related pathways. Life Sci 2006; 78: 869-874

75 Lu MC, Yang SH, Hwang SL, Lu YJ, Lin YH, Wang SR, Wu YC, Lin SR. Induction of G2/M phase arrest by squamocin in chronic myeloid leukemia (K562) cells. Life Sci 2006; 78: 2378-2383

76 Rupprecht JK, Chang CJ, Cassady JM, McLaughlin JL, Mikolajczak KL, Weisleder $D$. Asimicin, a new cytotoxic and pesticidal acetogenin from the pawpaw, Asimina triloba (Annonaceae). Heterocycles 1986; 24: 11971201

77 Ratnayake S, Rupprecht JK, Potter WM, McLaughlin JL. Evaluation of various parts of the paw paw tree, Asimina triloba (Annonaceae), as commercial sources of the pesticidal Anonaceous acetogenins. J Econ Entomol 1992; 85: 2353-2356

78 He K, Zeng L, Ye Q Shi G, Oberlies NH, Zhao GX, Njoku CJ, McLaughlin JL. Comparative structure-activity relationship evaluations of Anonaceous acetogenins for pesticidal activity. Pestic Sci 1997; 49: 372-378

79 Alali FQ Kaakeh W, Bennett GW, McLaughlin JL. Annonaceous acetogenins as natural pesticides: potent toxicity against insecticide-susceptible and -resistant German cockroaches (Dictyoptera: Blattellidae). J Econ Entomol 1998; 91: 641-649

80 Ohsawa K, Atsuzawa S, Mitsui T, Yamamoto I. Isolation and insecticidal activity of three acetogenins from seeds of pond apple, Annona glabra L. Nippon Noyaku Gakkaishi 1991; 16: 93-96

81 Guadano A, Gutierrez C, De la Pena E, Cortes D, Gonzalez-Coloma A. Insecticidal and mutagenic evaluation of two Anonaceous acetogenins. J Nat Prod 2000; 63: 773-776

82 Lewis MA, Arnason JT, Philogene BJR, Rupprecht JK, McLaughlin JL. Inhibition of respiration at site I by asimicin, an insecticidal acetogenin of the pawpaw, Asimina triloba (Annonaceae). Pestic Biochem Physiol 1993; 45: 15-23

83 Friedrich T, Ohnishi T, Forche E, Kunze B, Jansen R, Trowitzsch W, Hoefle $G$, Reichenbach $H$, Weiss $H$. Two binding sites for naturally occurring inhibitors in mitochondrial and bacterial NADH : ubiquinone oxidoreductase (complex I). Biochem Soc Trans 1994; 22: 226-230

84 Hollingworth RM, Ahammadsahib KI, Gadelhak G, McLaughlin JL. New inhibitors of complex I of the mitochondrial electron transport chain with activity as pesticides. Biochem Soc Trans 1994; 22: 230-233

85 Miyoshi H, Ohshima M, Shimada H, Akagi T, Iwamura H, McLaughlin JL. Essential structural factors of Annonaceous acetogenins as potent inhibitors of mitochondrial complex I. Biochim Biophys Acta 1998; 1365: 443-452

86 Miyoshi H. Inhibitors of mitochondrial respiratory enzymes. J Pestic Sci 2005; 30: 120-121

87 Takada M, Kuwabara K, Nakato H, Tanaka A, Iwamura H, Miyoshi H. Definition of crucial structural factors of acetogenins, potent inhibitors of mitochondrial complex I. Biochim Biophys Acta 2000; 1460: 302310

88 Murai M, Ichimaru N, Abe M, Nishioka T, Miyoshi H. Synthesis of photolabile $\Delta$ lac-acetogenin for photoaffinity labeling of mitochondrial complex I. J Pestic Sci 2006; 31: 156-158

89 Ichimaru N, Yoshinaga N, Nishioka T, Miyoshi H. Effect of stereochemistry of $\Delta$ lac-acetogenins on the inhibition of mitochondrial complex I (NADH-ubiquinone oxidoreductase). Tetrahedron 2007; 63: 11271139

90 Myint SH, Laurens A, Hocquemiller R, Cave A, Davoust D, Cortes D. Murisolin: a new cytotoxic mono-tetrahydrofuran- $\gamma$-lactone from Annona muricata. Heterocycles 1990; 31: 861-867 
91 Hattori Y, Kimura Y, Moroda A, Konno H, Abe M, Miyoshi H, Goto T, Makabe $H$. Synthesis of murisolin, $(15 R, 16 R, 19 R, 20 S)$-murisolin A and $(15 R, 16 R, 19 S, 20 S)-16,19$-cis-murisolin and their inhibitory action with bovine heart mitochondrial complex I. Chem Asian J 2006; 1: 894-904

92 Ye Q Zeng L, Zhang Y, Zhao GX, McLaughlin JL, Woo MH, Evert DR. Longicin and goniothalamicinone: novel bioactive monotetrahydrofuran acetogenins from Asimina longifolia. J Nat Prod 1995; 58: 1398-1406

93 Hanessian S, Giroux S, Buffat M. Total synthesis and structural confirmation of (+)-longicin. Org Lett 2005; 7: 3989-3992

94 Gleye C, Duret P, Laurens A, Hocquemiller R, Cave A. cis-Monotetrahydrofuran acetogenins from the roots of Annona muricata. J Nat Prod 1998; 61: 576-579

95 Goksel H, Stark CBW. Total synthesis of cis-solamin: exploiting the $\mathrm{RuO}_{4}$-catalyzed oxidative cyclization of dienes. Org Lett 2006; 8: 3433-3436

96 Zhao H, Gorman JST, Pagenkopf BL. Advances in Lewis acid controlled carbon-carbon bond-forming reactions enable a concise and convergent total synthesis of bullatacin. Org Lett 2006; 8: 4379-4382

97 Keum G, Hwang CH, Kang SB, Kim Y, Lee E. Stereoselective syntheses of rolliniastatin 1, rollimembrin, and membranacin. J Am Chem Soc 2005; 127: 10396-10399

98 Gonzalez MC, Tormo JR, Bermejo A, Zafra-Polo MC, Estornell E, Cortes D. Rollimembrin, a novel acetogenin inhibitor of mammalian mitochondrial complex I. Bioorg Med Chem Lett 1997; 7: 1113-1118

99 He K, Shi G, Zhao GX, Ye Q Schwedler JT, Wood KV, McLaughlin JL. Three new adjacent bis-tetrahydrofuran acetogenins with four hydroxyl groups from Asimina triloba. J Nat Prod 1996; 59: 1029-1034

100 Nattrass GL, Diez E, McLachlan MM, Dixon DJ, Ley SV. The total synthesis of the Annonaceous acetogenin 10-hydroxyasimicin. Angew Chem Int Ed Engl 2005; 44: 580-584

101 Saez J, Sahpaz S, Villaescusa L, Hocquemiller R, Cave A, Cortes D. Acetogenins of the Annonaceae. 18. Rioclarin and membranacin, two new bis-tetrahydrofuran acetogenins of the seeds of Rollinia membranacea. J Nat Prod 1993; 56: 351-356

102 Marshall JA, Sabatini JJ. An outside-in approach to adjacent bistetrahydrofuran Annonaceous acetogenins with $C_{2}$ core symmetry. Total synthesis of asimicin and a C32 analogue. Org Lett 2006; 8: 35573560

103 Ye Q He K, Oberlies NH, Zeng L, Shi G, Evert D, McLaughlin JL. Longimicins A - D: novel bioactive acetogenins from Asimina longifolia (Annonaceae) and structure-activity relationships of asimicin type of annonaceous acetogenins. J Med Chem 1996; 39: 1790-1796

104 Tominaga H, Maezaki N, Yanai M, Kojima N, Urabe D, Ueki R, Tanaka T. First total synthesis of longimicin D. Eur J Org Chem 2006; 2006: $1422-1429$

105 Shi G, Kozlowski JF, Schwedler JT, Wood KV, MacDougal JM, McLaughlin $J L$. Muconin and mucoxin: additional nonclassical bioactive acetogenins from Rollinia mucosa. J Org Chem 1996; 61: 7988-7989

106 Narayan RS, Borhan B. Synthesis of the proposed structure of mucoxin via regio- and stereoselective tetrahydrofuran ring-forming strategies. J Org Chem 2006; 71: 1416-1429

107 Shi G, Zheng L, Gu Z-M, MacDougal JM, McLaughlin JL. Absolute stereochemistries of sylvaticin and 12,15-cis-sylvaticin, bioactive C-20,23cis nonadjacent bistetrahydrofuran Annonaceous acetogenins, from Rollinia mucosa. Heterocycles 1995; 41: 1785-1796

108 Donohoe TJ, Harris RM, Burrows J, Parker J. Total synthesis of (+)-cissylvaticin: double oxidative cyclization reactions catalyzed by osmium. J Am Chem Soc 2006; 128: 13 704-13705

109 Alkofahi A, Rupprecht JK, Liu YM, Chang CJ, Smith DL, McLaughlin JL. Gigantecin: a novel antimitotic and cytotoxic acetogenin, with nonadjacent tetrahydrofuran rings, from Goniothalamus giganteus (Annonaceae). Experientia 1990; 46: 539-541

110 Hoye TR, Eklov BM, Jeon J, Khoroosi M. Sequencing of three-component olefin metatheses: total synthesis of either (+)-gigantecin or (+)-14deoxy-9-oxygigantecin. Org Lett 2006; 8: 3383-3386

111 Chavez D, Acevedo LA, Mata R. Jimenezin, a novel Annonaceous acetogenin from the seeds of Rollinia mucosa containing adjacent tetrahydrofuran-tetrahydropyran ring systems. J Nat Prod 1998; 61: 419421

112 Bandur NG, Bruckner D, Hoffmann RW, Koert U. Total synthesis of jimenezin via an intramolecular allylboration. Org Lett 2006; 8: 38293831
113 Shi G, Alfonso D, Fatope MO, Zeng L, Gu ZM, Zhao GX, He K, MacDougal JM, McLaughlin JL. Mucocin: a new Annonaceous acetogenin bearing a tetrahydropyran ring. J Am Chem Soc 1995; 117: 10 409-10410

114 Crimmins MT, Zhang Y, Diaz FA. Total synthesis of (-)-mucocin. Org Lett 2006; 8: 2369-2372

115 Alali FQ Rogers L, Zhang Y, McLaughlin JL. Unusual bioactive Annonaceous acetogenins from Goniothalamus giganteus. Tetrahedron 1998; 54: 5833-5844

116 Strand D, Rein T. Total synthesis of pyranicin. Org Lett 2004; 7: 199202

117 Strand D, Rein T. Synthesis of pyragonicin. Org Lett 2005; 7: 27792781

118 Takahashi S, Ogawa N, Koshino H, Nakata T. Total synthesis of the proposed structure for pyragonicin. Org Lett 2005; 7: 2783-2786

119 Quinn KJ, Isaacs AK, DeChristopher BA, Szklarz SC, Arvary RA. Asymmetric total synthesis of rollicosin. Org Lett 2005; 7: 1243-1245

120 Makabe H, Kimura Y, Higuchi M, Konno H, Murai M, Miyoshi H. Synthesis of $(4 R, 15 R, 16 R, 21 S)$ - and $(4 R, 15 S, 16 S, 21 S)$-rollicosin, squamostolide, and their inhibitory action with bovine heart mitochondrial complex I. Bioorg Med Chem 2006; 14: 3119-3130

121 Hoppen S, Emde U, Friedrich T, Grubert L, Koert U. Natural-product hybrids: design, synthesis, and biological evaluation of quinone-Annonaceous acetogenins. Angew Chem Int Ed Engl 2000; 39: 2099-2102

122 Arndt S, Emde U, Baurle S, Friedrich T, Grubert L, Koert U. Quinone-Annonaceous acetogenins: synthesis and complex I inhibition studies of a new class of natural product hybrids. Chem Eur J 2001; 7: 993-1005

123 Duval R, Lewin G, Hocquemiller R. Semisynthesis of heterocyclic analogues of squamocin, a cytotoxic annonaceous acetogenin, by an unusual oxidative decarboxylation reaction. Bioorg Med Chem 2003; 11: 3439-3446

124 Duval RA, Lewin G, Peris E, Chahboune N, Garofano A, Droese S, Cortes $D$, Brandt $U$, Hocquemiller $R$. Heterocyclic analogues of squamocin as inhibitors of mitochondrial complex I. On the role of the terminal lactone of Annonaceous acetogenins. Biochemistry 2006; 45: 27212728

125 Duval RA, Poupon E, Romero V, Peris E, Lewin G, Cortes D, Brandt U, Hocquemiller $R$. Analogues of cytotoxic squamocin using reliable reactions: new insights into the reactivity and role of the $\alpha, \beta$-unsaturated lactone of the Annonaceous acetogenins. Tetrahedron 2006; 62: 6248-6257

126 Kojima N, Fushimi T, Maezaki N, Tanaka T, Yamori T. Synthesis of hybrid acetogenins, $\alpha, \beta$-unsaturated- $\gamma$-lactone-free nitrogen-containing heterocyclic analogues, and their cytotoxicity against human cancer cell lines. Bioorg Med Chem Lett 2008; 18: 1637-1641

127 Zeng BB, Wu Y, Yu Q Wu YL, Li Y, Chen XG. Enantiopure simple analogues of Annonaceous acetogenins with remarkable selective cytotoxicity towards tumor cell lines. Angew Chem Int Ed 2000; 39: 1934-1937

128 Rodier S, Le Huerou Y, Renoux B, Doyon J, Renard P, Pierre A, Gesson JP, Gree $R$. Synthesis and cytotoxic activity of acetogenin analogues. Bioorg Med Chem Lett 2000; 10: 1373-1375

129 Yao ZJ, Wu HP, Wu YL. Polyether mimics of naturally occurring cytotoxic Annonaceous acetogenins. J Med Chem 2000; 43: 2484-2487

130 Jiang S, Liu ZH, Sheng G, Zeng BB, Cheng XG, Wu YL, Yao ZJ. Mimicry of Annonaceous acetogenins: enantioselective synthesis of a (4R)-hydroxy analogue having potent antitumor activity. J Org Chem 2002; 67: 3404-3408

131 Zeng BB, Wu Y, Jiang S, Yu Q Yao ZJ, Liu ZH, Li HY, Li Y, Chen XG, Wu YL. Studies on mimicry of naturally occurring Annonaceous acetogenins: non-THF analogues leading to remarkable selective cytotoxicity against human tumor cells. Chem Eur J 2003; 9: 282-290

132 Rodier S, Le Huerou Y, Renoux B, Doyon J, Renard P, Pierre A, Gesson JP, Gree $R$. New cytotoxic analogues of Annonaceous acetogenins. Anticancer Drug Des 2001; 16: 109-117

133 Fujita D, Ichimaru N, Abe M, Murai M, Hamada T, Nishioka T, Miyoshi H. Synthesis of non-THF analogs of acetogenin toward simplified mimics. Tetrahedron Lett 2005; 46: 5775-5779

134 Liu HX, Huang GR, Zhang HM, Wu JR, Yao ZJ. Annonaceous acetogenin mimics bearing a terminal lactam and their cytotoxicity against cancer cells. Bioorg Med Chem Lett 2007; 17: 3426-3430

135 Liu HX, Shao F, Li GQ Xun GL, Yao ZJ. Tuning the acyclic ether moiety of anticancer agent AA005 with conformationally constrained fragments. Chem Eur J 2008; 14: 8632-8639

136 Ye Q Shi G, He K, McLaughlin JL. Chlorinated Annonaceous acetogenins and their bioactivities. J Nat Prod 1996; 59: 994-996 
137 Kojima N, Hayashi H, Suzuki S, Tominaga H, Maezaki N, Tanaka T, Yamori T. Synthesis of C4-fluorinated solamins and their growth inhibitory activity against human cancer cell lines. Bioorg Med Chem Lett 2008; 18: 6451-6453

138 Gallardo T, Saez J, Granados H, Tormo JR, Velez ID, Brun N, Torres B, Cortes $D$. 10-Oximeguanacone, the first nitrogenated acetogenin derivative found to be a potent inhibitor of mitochondrial complex I. J Nat Prod 1998; 61: 1001-1005

139 Duret P, Hocquemiller R, Gantier JC, Figadere B. Semisynthesis and cytotoxicity of amino acetogenins and derivatives. Bioorg Med Chem 1999; 7: 1821-1826

140 Derbre S, Roue G, Poupon E, Susin Santos A, Hocquemiller R. Annonaceous acetogenins: the hydroxyl groups and THF rings are crucial structural elements for targeting the mitochondria, demonstration with the synthesis of fluorescent squamocin analogues. Chembiochem 2005; 6: 979-982

141 Alexander MD, Burkart MD, Leonard MS, Portonovo P, Liang B, Ding X, Joullie MM, Gulledge BM, Aggen JB, Chamberlin AR, Sandler J, Fenical W, Cui J, Gharpure SJ, Polosukhin A, Zhang HR, Evans PA, Richardson $A D$, Harper MK, Ireland CM, Vong BG, Brady TP, Theodorakis EA, La Clair $\mathrm{JJ}$. A central strategy for converting natural products into fluorescent probes. Chembiochem 2006; 7: 409-416

142 Maezaki N, Urabe D, Yano M, Tominaga H, Morioka T, Kojima N, Tanaka $T$. Synthesis of fluorescent solamin for visualization of cell distribution. Heterocycles 2007; 73: 159-164

143 Kojima N, Morioka T, Yano M, Suga Y, Maezaki N, Tanaka T. Convergent synthesis of fluorescence labeled solamin. Heterocycles 2009; 79: 387-393

144 Liu HX, Huang GR, Zhang HM, Jiang S, Wu JR, Yao ZJ. A structure-activity guided strategy for fluorescent labeling of Annonaceous acetogenin mimetics and their application in cell biology. Chembiochem 2007; 8: 172-177

145 Zafra-Polo MC, Gonzalez MC, Estornell E, Sahpaz S, Cortes D. Acetogenins from Annonaceae, inhibitors of mitochondrial complex I. Phytochemistry 1996; 42: 253-271

146 Sasaki S, Naito H, Maruta K, Kawahara E, Maeda M. Novel calcium ionophores: supramolecular complexation by the hydroxylated-bistetrahydrofuran skeleton of potent antitumor annocnaceous acetogenins. Tetrahedron Lett 1994; 35: 3337-3340
147 Araya H, Fujimoto Y, Hirayama K. Structural elucidation of tetrahydrofuranic acetogenins by means of precursor-ion scanning method. Yuki Gosei Kagaku Kyokaishi 1994; 52: 765-777

148 Sasaki S, Maruta K, Naito H, Sugihara H, Hiratani K, Maeda M. New calcium-selective electrodes based on Annonaceous acetogenins and their analogs with neighboring bistetrahydrofuran. Tetrahedron Lett 1995; 36: 5571-5574

149 Sasaki S, Maruta K, Naito H, Maemura R, Kawahara E, Maeda M. Novel acyclic ligands for metal cations based on the adjacent bistetrahydrofuran as analogs of natural Annonaceous acetogenins. Tetrahedron 1998; 54: 2401-2410

150 Peyrat JF, Mahuteau J, Figadere B, Cave A. NMR studies of $\mathrm{Ca}^{2+} \mathrm{com}-$ plexes of Annonaceous acetogenins. J Org Chem 1997; 62: 4811-4815

151 Wu SN, Chiang HT, Chang FR, Liaw CC, Wu YC. Stimulatory effects of squamocin, an Annonaceous acetogenin, on $\mathrm{Ca}^{2+}$-activated $\mathrm{K}^{+}$current in cultured smooth muscle cells of human coronary artery. Chem Res Toxicol 2003; 16: 15-22

152 Liaw CC, Yang YL, Chen M, Chang FR, Chen SL, Wu SH, Wu YC. Mono-tetrahydrofuran Annonaceous acetogenins from Annona squamosa as cytotoxic agents and calcium ion chelators. J Nat Prod 2008; 71: 764-771

153 Gu ZM, Zhou D, Lewis NJ, Wu J, Johnson HA, McLaughlin JL, Gordon J. Quantitative evaluation of Annonaceous acetogenins in monthly samples of paw paw (Asimina triloba) twigs by liquid chromatography/ electrospray ionization/tandem mass spectrometry. Phytochem Anal 1999; 10: 32-38

154 McLaughlin JL. Paw paw and cancer: Annonaceous acetogenins from discovery to commercial products. J Nat Prod 2008; 71: 1311-1321

155 Cuendet M, Oteham CP, Moon RC, Keller WJ, Peaden PA, Pezzuto JM. Dietary administration of Asimina triloba (Paw Paw) extract increases tumor latency in $\mathrm{N}$-methyl- $\mathrm{N}$-nitrosourea-treated rats. Pharm Biol 2008; 46: 3-7

156 Escobar-Khondiker M, Hoellerhage M, Muriel MP, Champy P, Bach A, Depienne C, Respondek G, Yamada ES, Lannuzel A, Yagi T, Hirsch Etienne C, Oertel WH, Jacob R, Michel PP, Ruberg M, Hoeglinger GU. Annonacin, a natural mitochondrial complex I inhibitor, causes Tau pathology in cultured neurons. J Neurosci 2007; 27: 7827-7837 